\title{
The Impact of Intra-Industry Trade on the Environment
}

\author{
K.C. Fung* and Andréa M. Maechler** \\ Department of Economics \\ University of California, Santa Cruz \\ Santa Cruz, CA 95064
}

Last Revision: October 15, 1999

\begin{abstract}
By addressing environmental protection in the context of intra-industry trade, this paper offers a new perspective on the trade and environment debate. Empirical evidence has long suggested that an increasing share of international trade takes the form of intra- rather than inter-industry trade. Thus, it is essential to discuss the likely impact of trade on the environmental quality in the context of two-way trade. Using a simple intra-industry trade model à la Brander and Krugman (1983), this essay shows that environmental consequences of trade liberalization differ significantly when oligopolistic rivalry rather than comparative advantage drives international trade.
\end{abstract}


The Impact of Intra-Industry Trade on the Environment

\section{Introduction}

Recent years have witnessed two interesting developments in trade theory, namely, the emergence of intra-industry trade as a widespread phenomenon and a revitalization of the concern about the environmental consequences of international trade. By providing a link between these two strands of the literature, this paper departs from the standard inter-industry trade approaches used in the trade-environment debate and offers a new perspective.

The concept of intra-industry emerged when it became apparent that much of the trade growth experienced over the last fifty years is attributable to an increase in two-way trade within the same industry. This is particularly true for the manufacturing sector, among which rank some of the most pollution-intensive industries, including chemicals, metallurgy, mining, and paper and pulp. For illustration, Table 1 presents indexes of intra-industry trade for selected U.S. manufacturing industries in 1993. An index close to one (such as 0.99 for inorganic chemicals) indicates that for this industry the U.S. imports almost as much as it exports, while an index close to zero indicates that for this industry, the U.S. is only an exporter or an importer (such as 0.20 for footwear). ${ }^{1} \quad$ While earlier empirical work focuses on industrial countries, more recent studies suggest that this phenomenon is not limited to industrialized countries and can be significant in developing countries. ${ }^{2} \quad$ In fact, a new

\footnotetext{
1 For a recent empirical study of intra-industry trade in pollution-intensive homogeneous products, see the recent work by Bernhofen (1999). This paper uses the Brander (1981) model of intra-industry trade in identical commodities to conduct an empirical investigation in the context of the petrochemical industry in Germany and the United States.

2 For a comprehensive survey of the literature on intra-industry trade, see Greenaway and Milner (1986) and Helpman (1987). Tharakan (1984) provides evidence on intra-industry trade between OECD countries and
} 
consensus is emerging from recent experience suggesting that trade liberalization has been a powerful vehicle for the growth of intra-industry trade in a wide range of countries. ${ }^{3}$

Table 2.1:

Intra-Industry Trade for U.S. Industry, 1993
\begin{tabular}{|l|r|}
\hline Inorganic Chemicals & 0.99 \\
Power-Generating Machinery & 0.97 \\
Electric Machinery & 0.96 \\
Organic Chemicals & 0.91 \\
Medical and Pharmaceutical & 0.86 \\
Iron and Steel & 0.43 \\
Footwear & 0.29 \\
\hline
\end{tabular}
Source: Krugman and Obstfeld (1997)

The observation that an increasing share of trade expansion is taking the form of intrarather than inter-industry trade is of particular importance when examining the far-reaching consequences of trade liberalization. While few trade economists deny that trade liberalization generally incurs significant adjustment costs in terms of resource re-allocation, at least in the short to medium run, they generally recognize that the magnitude of these costs depends crucially on the extent to which trade liberalization leads to increased inter- versus intra-industry trade. ${ }^{4}$ For example, when trade liberalization results in inter-industry the developing world.

3 For example, Hoekman and Djankov (1996) presents evidence for trade liberalization-induced intra-industry trade expansion in Eastern Europe, Lee and Lee (1993) in Korea and Menon (1994) in Australia.

4 Krugman (1981), for example, shows that in the context of intra-industry trade it is possible for all factors of production to gain, which can alleviate adjustment costs. See Menon and Dixon $(1996,1997)$ for a general discussion on factor market disruption under inter- versus intra-industry trade. 
trade expansion, factors of production are transferred from import-competing industries to export-oriented industries, whereas they are switched across different product lines within the same industry in the case of intra-industry trade expansion. Since the costs of shifting resources across an industry are likely to be much lower than those of shifting resources between industries, a trade liberalization is also likely to yield very different effects depending on the underlying source of trade. Recognizing this crucial role of the structure of trade is of great relevance to the core argument of this paper, which addresses the interactions between international trade and the quality of the environment in the presence of intra-industry factor movement. ${ }^{5}$

Clearly, the environmental consequences of international trade depend on the underlying source of trade. And yet, the question of international trade and the environment has not been addressed in the context of intra-industry trade. Thus, the purpose of this paper is to fill this gap in the literature and to add elements of intra-industry trade to the current debate on trade and the environment.

At the heart of the current debate around the environmental consequences of trade lie three separate effects, namely, the scale effect that always increases pollution (trade induces more output, which means more pollution); the technique effect that always decreases pollution (trade makes cleaner technologies available, which reduces pollution) and the com-

5 For excellent surveys on the environment-trade nexus, see Anderson and Blackhurst (1992), Beghin, RolandHolst and van der Mensbrugghe (1994) and Low (1992). See Bhagwati and Hudec (1997) for critical discussions on the international harmonization of environmental standards. Finally, Rauscher (1997) offers an insightful chapter on the interlinkages between trade and the environment in an imperfect competition framework. Although the main focus of his work considers how environmental policies can be used to achieve trade-related policy objectives, he introduces a model monopolistic competition model to sketch some of the environmental consequences of intra-industry trade. 
position effect (trade alters the pattern of production). ${ }^{6}$ To isolate the link between intraindustry factor relocation and environmental damage, we put aside both, the technique and the scale effects and focus on the third and largely contentious effect, that is, the composition effect of trade. ${ }^{7}$

So far, the literature identifies two main hypotheses in support of the composition effect. The first hypothesis is the "simple factor endowment" hypothesis. According to this hypothesis, the relatively low-income and environment-intensive developing countries with lax environmental regulations will specialize in the production of pollution-intensive goods and hence, will be made dirtier with trade. A different version of this hypothesis suggests that trade will cause the dirty capital-intensive processes to be relocated to the relatively capital-abundant developed countries. In either case, this hypothesis predicts that the environmental consequences of trade will be determined by some kind of factor-abundance mechanism, whether the environment-abundant country specializes in the environment-intensive (and polluting) goods or the capital-abundant country specializes in capital-intensive (and polluting) goods. The "pollution-haven" or "dirty industry migration" hypothesis is the second hypothesis, which suggests that dirty industries will relocate from the industrialized

6 This decomposition is first introduced in Grossman and Krueger (1993, 1995), elaborated in Copeland and Taylor $(1994,1995)$ and then tested in Antweiler, Copeland and Taylor (1998). Note that the scale and technique effects can incorporate the income effect, which is discussed in Copeland (1995), Copeland and Taylor (1994) and Grossman and Krueger (1993).

7 The technique effect relies on a very different set of theoretical premises dealing with the role of technological progress. The scale effect requires a general equilibrium analysis, while our model, which follows the tradition of the new oligopoly literature, is set in a partial equilibrium framework. It is important to keep in mind, however, that whatever the environmental consequences of trade via the composition effect are (which Antweiler, Copeland and Taylor (1998) finds to be only slightly negative), the full impact of trade may be either positive or negative, depending on the relative strength of the (positive) technique and the (negative) scale effects. 
countries with tougher environmental standards to the lower-income countries which require lower environmental standards. All of these hypotheses rely on the theory of comparative advantage to predict how trade alters the composition of national output and thereby, the quality of the environment. ${ }^{8}$ In other words, both hypotheses explain environmental degradation in terms of inter-industry factor relocation.

The present paper, however, offers a very different approach to address the trade-environment nexus and focuses on intra-industry trade as the main culprit of environmental degradation. In this context, the composition effect of trade generates a very different kind of change in the pattern of production, namely, one that is fueled by oligopolistic interactions rather than one that alters the economy's industry commodity mix as predicted under standard inter-industry trade.

By restricting our analysis to the context of oligopolistic intra-industry trade, our model isolates the source of trade to be determined solely by the strategic interactions of oligopolistic polluting firms and not by cost differences and/or by economies of scale. ${ }^{9} \quad$ In reality, of course, the determinants of trade are manifold, including differences in factor endowments, in income levels, in technological capabilities and in regulatory and institutional frameworks. But we argue that empirically, it is actually more relevant to look at intra-industry trade to discuss the likely impact of international trade on the quality of the environment.

\footnotetext{
8 The theory of comparative advantage predicts that a country tends to export products that use intensively the factors of production with which it is relatively well endowed, and import those that use intensively its scarce factors. With respect to the environment, the effects of trade depend on whether a country becomes an exporter or an importer of pollution-intensive goods in the post-liberalization situation. In the absence of transboundary pollution, trade is good for the domestic environment in the former case, while it is bad in the latter case.

9 Note that intra-industry trade in the context of monopolistic competition would use economies of scale as a key determinant of environmental deterioration.
} 
This paper is organized as follows. Section 2 presents our basic duopoly model of intraindustry trade and derives the environmental consequences of trade liberalization under local, transboundary and global pollution. Section 3 extends the basic model to verify the validity of our results in the presence of multiple firms. In section 4, we examine how trade collusion alters our basic results. In sections 5 and 6 , we introduce foreign direct investment (FDI). While section 5 focuses on how trade liberalization affects the quality of the environment when only one country engages in FDI activities, section 6 considers the case where both countries engage in FDI activities. Finally, concluding comments are provided in section 7.

\section{Basic Model}

\subsection{Framework}

We develop a standard intra-industry trade model in the tradition of Brander (1981) and Brander and Krugman (1983). There are two countries, a home country and a foreign country, each holding one polluting firm. Consumers consume goods which are produced both at home and abroad. Because most intra-industry trade occurs between similar economies, it is safe to assume that the two countries have similar tastes and endowments. The home (foreign) country produces a pollution-intensive good which is sold in the home (foreign) market and which can also be exported to the foreign (home) market. The profit function of, respectively, the home and the foreign firm is written as:

$$
\begin{gathered}
\pi_{\mathrm{x}}=x_{1} p_{\mathrm{x} 1}+x_{2} p_{\mathrm{x} 2}-e_{\mathrm{x}}\left(x_{1}+x_{2}\right)-t_{\mathrm{x}} x_{2} \\
\pi_{\mathrm{y}}=y_{1} p_{\mathrm{y} 1}+y_{2} p_{\mathrm{y} 2}-e_{\mathrm{y}}\left(y_{1}+y_{2}\right)-t_{\mathrm{y}} y_{1}
\end{gathered}
$$




\section{The Impact of Intra-Industry Trade on the Environment}

where $x_{\mathrm{i}}(i=1,2)$ represents a pollution-intensive good that is produced in the home country and $y_{\mathrm{i}}(i=1,2)$ represents a pollution-intensive good that is produced in the foreign country. The subscripts indicate whether a good is sold in the home market (1) or in the foreign market $(2)$.

For example, while the first term in equation (1) represents the domestic sales of the home firm, the second term represents its export sales. The third term represents the home pollution tax $e_{\mathbf{x}}$, which the home country imposes on all home-produced pollution-intensive goods, regardless of whether they are sold at home or abroad. Finally, the fourth term represents the foreign import tariff $t_{\mathrm{x}}$, which the home country faces when exporting its pollution-intensive production abroad. Similarly for the foreign profit function in equation (2), where the first term represents its export sales to the home country, the second term represents its domestic sales to the foreign market, the third term represents the foreign pollution tax $e_{\mathrm{y}}$ imposed on the foreign-produced pollution-intensive good and the fourth term represents the home import tariff $t_{\mathrm{y}}$ imposed on foreign exports.

To highlight the environmental effects of trade liberalization, we assume zero production and transportation costs and focus solely on pollution taxes and/or trade protection. While the assumption of zero production and transportation costs greatly simplifies the interpretation of the results, it does not affect its general conclusions.

We assume a symmetric linear demand structure and allow for differentiated goods (that 
is, we assume $\left.\beta_{1}=\beta_{1} \neq \gamma\right)^{10}$ :

$$
\begin{aligned}
& p_{x_{\mathrm{i}}}=\alpha_{1}-\beta x_{\mathrm{i}}-\gamma y_{\mathrm{i}} \\
& p_{\mathrm{y}_{\mathrm{i}}}=\alpha_{2}-\beta y_{\mathrm{i}}-\gamma x_{\mathrm{i}}
\end{aligned}
$$

where $\alpha_{\mathrm{i}}(i=1,2)>0, \beta>0$, and $\gamma>0$. Assuming that the firms are Cournot-Nash players, the first-order profit maximization conditions yield the following outputs:

$$
\begin{aligned}
& x_{1}^{\mathrm{CN}}=\frac{2 \beta_{2}\left(\alpha_{1}-e_{\mathrm{x}}\right)-\gamma\left(\alpha_{2}-e_{\mathrm{y}}-t_{\mathrm{y}}\right)}{D} \\
& x_{2}^{\mathrm{CN}}=\frac{2 \beta_{2}\left(\alpha_{1}-e_{\mathrm{x}}-t_{\mathrm{x}}\right)-\gamma\left(\alpha_{2}-e_{\mathrm{y}}\right)}{D} \\
& y_{1}^{\mathrm{CN}}=\frac{2 \beta_{1}\left(\alpha_{2}-e_{\mathrm{y}}-t_{\mathrm{y}}\right)-\gamma\left(\alpha_{1}-e_{\mathrm{x}}\right)}{D} \\
& y_{2}^{\mathrm{CN}}=\frac{2 \beta_{1}\left(\alpha_{2}-e_{\mathrm{y}}\right)-\gamma\left(\alpha_{1}-e_{\mathrm{x}}-t_{\mathrm{x}}\right)}{D}
\end{aligned}
$$

where $D={ }^{\mathbf{i}} 4 \beta^{2}-\gamma^{2^{\$}}$. Note that the concavity assumption of the aggregate utility function $U_{\mathrm{i}}$ associated with the above demand functions implies that $\left(\beta^{2}-\gamma^{2}\right)>0$. Furthermore, we assume that the own-price effects are greater than the cross-price effects, that is, $\beta>\gamma$.

\subsection{Conditions for Intra-Industry Trade}

The existence of intra-industry trade requires that $x_{2}^{\mathrm{CN}}>0$ and $y_{1}^{\mathrm{CN}}>0$. Thus, the conditions for intra-industry trade can be expressed as:

$$
x_{2}^{\mathrm{CN}}>0 \quad \text { iff } \quad \frac{2 \beta}{\gamma}>\frac{\left(\alpha_{2}-e_{\mathrm{y}}\right)}{\left(\alpha_{1}-e_{\mathrm{x}}-t_{\mathrm{x}}\right)}
$$

(8)This demand stracture is associated the following aggregate utility function: $U_{\mathrm{i}}=w_{\mathrm{i}}+m_{\mathrm{i}}$ where $w_{\mathrm{i}}=$ $\alpha_{1} x_{\mathrm{i}}+\alpha_{2} y_{\mathrm{i}}-\frac{1}{2} \beta\left(x_{\mathrm{i}}^{2}+y_{\mathrm{i}}^{2}\right)+2 \gamma x_{\mathrm{i}} y_{\mathrm{i}} \quad$ represents the expenditure on $x_{\mathrm{i}}$ and $y_{\mathrm{i}}$ and $m_{\mathrm{i}}$ the expenditures on all other goods in country $i$. 


$$
y_{1}^{\mathrm{CN}}>0 \quad \text { iff } \frac{2 \beta}{\gamma}>\frac{\left(\alpha_{1}-e_{\mathrm{x}}\right)}{\left(\alpha_{2}-e_{\mathrm{y}}-t_{\mathrm{y}}\right)}
$$

According to the above conditions, intra-industry trade is more likely to occur in the presence of: (i) greater product differential (high $\beta / \gamma$ ); (ii) low import tariffs, $t_{i}$; and (iii) lower environmental standards imposed on the exporting country $i$ (high $\alpha_{\mathrm{i}}-e_{\mathrm{i}}$ ).

\subsection{Unilateral Trade Liberalization}

Assume that the home (foreign) country implements a unilateral trade liberalization, such that $d t_{\mathrm{y}}<0\left(d t_{\mathrm{x}}<0\right)$. The impact of such a trade policy on the demand for pollutionintensive goods is given in the following equations:

$$
\begin{gathered}
\frac{\partial x_{1}^{\mathrm{CN}}}{\partial t_{\mathrm{y}}}=\frac{\gamma}{D}>0 \\
\frac{\partial y_{1}^{\mathrm{CN}}}{\partial t_{\mathrm{y}}}=-\frac{2 \beta_{1}}{D}<0
\end{gathered}
$$

By unilaterally liberalizing trade, the home country facilitates the access of foreign pollution-intensive goods into the home market. This allows the home country to increase its consumption of the foreign-produced polluting good and to reduce its consumption of the domestically-produced polluting good. Given our earlier assumption that the own-price effects exceed the cross-price effects, the increase in imports exceeds the fall in the demand for the domestically produced good and, on aggregate, a unilateral trade increases the domestic consumption of the pollution-intensive good. Similarly for a foreign trade liberalization, which increases the demand for the imported good by more than it decreases the demand 
for the domestically-produced polluting good.

$$
\begin{gathered}
\frac{\partial x_{2}^{\mathrm{CN}}}{\partial t_{\mathrm{x}}}=-\frac{2 \beta_{2}}{D}<0 \\
\frac{\partial y_{2}^{\mathrm{CN}}}{\partial t_{\mathrm{x}}}=\frac{\gamma}{D}>0
\end{gathered}
$$

In summary, a unilateral trade liberalization $\left(d t_{\mathrm{i}}<0\right)$ raises the pollution-intensive output in the country benefiting from trade liberalization and lowers it in the liberalizing country. Furthermore, the liberalizing country increases its aggregate consumption of the pollution-intensive good.

\subsection{Environmental Damage}

In this section, we focus on how a unilateral trade liberalization affects the environment in a world where the quality of the environment is a by-product of the production of pollutionintensive goods. ${ }^{11}$ To tackle this question, we assume that pollution harms consumers without affecting the production possibility frontier and that the source of pollution may lie outside of national boundaries. We differentiate between three types of pollution, namely:

(i) local pollution; (ii) transboundary pollution; and (iii) global pollution. ${ }^{12}$

Although there exists no strict line delimiting local pollution from transboundary or even global pollution, the impact of various types of production-generated pollutions on the

\footnotetext{
11 Although most of the existing theoretical work focuses on production-generated pollution, Copeland and Taylor $(1995,1999)$ examine, respectively, pollution as a by-product of consumption and pollution as it affects productivity.

12Although there is an extensive literature on transboundary pollution (see Dean 1992 for a survey), there is little work examining the environmental consequences of trade in an imperfect competitive framework and even less in an intra-industry setting (see Rauscher 1997).
} 
environmental quality may be very different in scope. When pollution is local, a country's environmental damage is determined entirely by its domestic polluting production. Examples of local pollution abound and include urban air pollution, local soil erosion and local contamination of water, air and land. When pollution is transboundary, environmental damage spills across national boundaries and the quality of a country's environment is determined by the sum of two components, namely, the pollution generated by its own domestic polluting production and a fraction of the pollution generated during the polluting production abroad. Acid rain, for example, is often cited as an illustration of transboundary pollution. The production of certain pollution-intensive goods releases pollutants in the air, which are then carried by winds hundreds of miles away from their production site before being deposited again in the atmosphere through rain, fog or snow. In this situation, a country cares about the type and the quantity of pollution generated abroad. Finally, when pollution is global, a country's environmental damage is determined by the aggregate pollution-intensive production, regardless of the country of production. Examples of global pollution include the deterioration of the ecosystem, the depletion of the ozone layer and global warming.

The environmental damage of, respectively, the home and the foreign country, can be written as:

$$
\begin{aligned}
& E d_{\mathrm{x}}=d_{\mathrm{x}}\left(x_{1}+x_{2}\right)+\eta_{\mathrm{y}} d_{\mathrm{y}}\left(y_{1}+y_{2}\right) \\
& E d_{\mathbf{y}}=d_{\mathbf{y}}\left(y_{1}+y_{2}\right)+\eta_{\mathbf{x}} d_{\mathbf{x}}\left(x_{1}+x_{2}\right)
\end{aligned}
$$

where $d_{\mathrm{i}}(i=x, y)$ represents the environmental damage associated with the production of the pollution-intensive goods $x_{\mathrm{i}}$ and $y_{\mathrm{i}} \cdot \eta_{\mathrm{i}}$ represents the pollution spillover and illustrates 
the extent to which pollution generated in one country damages the environment in the other country. ${ }^{13}$ At one extreme, $\eta_{\mathrm{i}}$ is zero and one country's pollution does not affect the quality of the environment in the other country. This is the case of local pollution. At the other extreme, $\eta_{\mathrm{i}}$ is equal to one and pollution produced in either country affects both countries equally. This is when pollution is global. Finally, if $\eta_{\mathrm{i}}$ lies somewhere between zero and one, pollution is transboundary. In this case, although no country is completely insulated from the other country's pollution, the damage that a country incurs from its own pollution is greater than the damage it incurs from the pollution generated abroad.

To clarify our analysis, we make two further assumptions. First, we assume that the home country is the 'clean' country, in the sense that it imposes a higher pollution tax than the foreign country, or, $e_{\mathbf{x}}>e_{\mathbf{y}}$. Second, and related to our first assumption, we also assume that for an equal level of production the stricter environmental standards induce the clean country to generates less pollution than the foreign country or, $d_{\mathrm{x}}<d_{\mathrm{y}}$. Henceforth, unless specified otherwise, we will use interchangeably the terms of home and clean country on the one hand, and of foreign and dirty country on the other hand.

We can turn now to the effects of a unilateral trade liberalization on the environment. 13While there is an extensive literature on transboundary pollution, it is mostly concerned with how environmental regulations affect trade, rather than how trade affects the quality of the environment (Siebert, 1977 and Baumol and Oates, 1988). See Copeland and Taylor (1993, 1995) for a discussion on the role of transboundary pollution in the debate over trade and the environment. 


\section{The Impact of Intra-Industry Trade on the Environment}

\subsubsection{Local Pollution}

When pollution is local, the environmental damage of, respectively, the home and the foreign country, is given by:

$$
\begin{aligned}
& E d_{\mathrm{x}}^{\mathrm{l}}=d_{\mathrm{x}}\left(x_{1}+x_{2}\right) \\
& E d_{\mathrm{y}}^{\prime}=d_{\mathrm{y}}\left(y_{1}+y_{2}\right)
\end{aligned}
$$

Clearly, a country raises (lowers) the quality of its environment if it decreases (increases) its pollution-intensive production. The effects of a unilateral trade liberalization by the clean country on the environmental damage of, respectively, the clean and the dirty country, are given by:

$$
\begin{gathered}
\frac{\partial E d_{\mathrm{x}}^{\mathrm{x}}}{\partial t_{\mathrm{y}}}=\frac{\gamma d_{\mathrm{x}}}{D}>0 \\
\frac{\partial E d_{\mathrm{y}}^{l}}{\partial t_{\mathrm{y}}}=-\frac{2 \beta d_{\mathrm{y}}}{D}<0
\end{gathered}
$$

We have seen above that a unilateral trade liberalization raises the output in the country benefiting from the liberalization and reduces it in the liberalizing country. Thus, the production of the pollution-intensive good is transferred away from the clean country towards the dirty country. This lowers the environmental damage in the clean country and raises it in the dirty country, or, put differently, this raises the quality of the environment in the clean country and deteriorates in the dirty country. 
Similarly, if the dirty country liberalizes trade, the production of the pollution-intensive good is shifted away from the dirty country towards the clean country. Thus, a unilateral trade liberalization by the dirty country lowers the environmental damage in the dirty country (which produces now less of the pollution-intensive good) and raises it in the clean country (which produces now more of the pollution-intensive good). This can be seen in the following equations:

$$
\begin{gathered}
\frac{\partial E d_{\mathrm{x}}^{1}}{\partial t_{\mathrm{x}}}=-\frac{2 \beta d_{\mathrm{x}}}{D}<0 \\
\frac{\partial E d_{\mathrm{y}}^{\mid}}{\partial t_{\mathrm{x}}}=\frac{\gamma d_{\mathrm{y}}}{D}>0
\end{gathered}
$$

These equations highlight one very interesting point, namely, that a unilateral trade liberalization actually improves the quality of the environment in the country that liberalizes trade, regardless of which country is liberalizing. This is a very different outcome than the one generally predicted under standard inter-industry trade models. This result can be formalized in the following terms.

Proposition 1 Assuming that pollution is local, a unilateral trade liberalization improves the quality of the environment in the liberalizing country and deteriorates it in the country benefiting from trade liberalization. This proposition holds regardless of whether the clean country or the dirty country is liberalizing.

\subsubsection{Transboundary Pollution}

In the presence of transboundary pollution, the environmental damage of, respectively, the home and the foreign country, can be written as:

$$
E d_{\mathrm{x}}^{\mathrm{t}}=d_{\mathrm{x}}\left(x_{1}+x_{2}\right)+\eta_{\mathrm{y}} d_{\mathrm{y}}\left(y_{1}+y_{2}\right)
$$




$$
E d_{\mathrm{y}}^{\mathrm{t}}=d_{\mathrm{y}}\left(y_{1}+y_{2}\right)+\eta_{\mathrm{x}} d_{\mathrm{x}}\left(x_{1}+x_{2}\right)
$$

where $0<\eta_{\mathrm{i}}<1$ (for $i=x, y$ ). Then, the effects of a unilateral trade liberalization by the home country on the environmental damage of, respectively, the home and the foreign country, are given by:

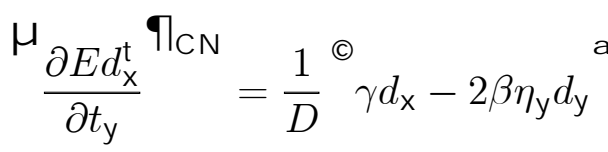

$$
\begin{aligned}
& {\frac{\mu E d_{\mathrm{y}}^{\mathrm{t}}}{\partial t_{\mathrm{y}}}}^{\text {ๆ } \mathrm{cN}}=\frac{1}{D}\left\{\gamma \eta_{\mathrm{x}} d_{\mathrm{x}}-2 \beta d_{\mathrm{y}}\right\}
\end{aligned}
$$

These equations can be re-written in the following conditional expressions:

$$
\begin{aligned}
& \frac{\partial E d_{\mathrm{x}}^{\mathrm{t}}}{\partial t_{\mathrm{y}}}>0 \quad \text { iff } \quad \frac{2 \beta}{\gamma}<\frac{d_{\mathrm{x}}}{\eta_{\mathrm{y}} d_{\mathrm{y}}} \\
& \frac{\partial E d_{\mathrm{y}}^{\mathrm{t}}}{\partial t_{\mathrm{y}}}>0 \quad \text { iff } \quad \frac{2 \beta}{\gamma}<\frac{\eta_{\mathrm{x}} d_{\mathrm{x}}}{d_{\mathrm{y}}}
\end{aligned}
$$

For notational purposes, we refer to the left-hand side of the above conditional statements as the "product differential" effect and to their right-hand side as country $i$ 's "relative pollution differential" effect, which is measured by country $i$ 's pollution damage parameter over country $j$ 's pollution damage parameter. For example, the right-hand side in expressions (15) and (16) refers to the home relative pollution differential.

We have seen that a unilateral trade liberalization by the clean country shifts the pollutionintensive production away from the clean country towards the dirty country. As long as the home country does not bear a large fraction of the foreign pollution (i.e., as long as the pollution spillover from abroad, $\eta_{\mathrm{y}}$, is not too large), the clean country (which benefits from lower 
production and hence, lower domestic pollution) improves the quality of its environment by unilaterally liberalizing trade. The quality of the environment in the foreign country, however, always deteriorates following a unilateral trade liberalization by the home country. This can be seen from equation (16), where the conditional statement never holds.

Assuming that the home relative pollution differential exceeds the product differential, we can summarize the results as follows:

Proposition 2 Assuming that pollution is transboundary, the clean country can improve its environment by unilaterally liberalizing trade. But the higher environmental quality in the clean country is always achieved at the expense of a deterioration in the environmental quality of the dirty country.

So far, we have considered the case where the clean country liberalizes trade. However, once pollution is no longer local, the effects of a trade liberalization on the quality of the environment are sensitive to which country is liberalizing trade. Thus, we turn now to the case where the dirty country is liberalizing trade.

$$
\begin{aligned}
& \frac{\partial E d_{\mathrm{x}}^{\mathrm{t}}}{\partial t_{\mathrm{x}}}>0 \quad \text { iff } \quad \frac{2 \beta}{\gamma}<\frac{\eta_{\mathrm{y}} d_{\mathrm{y}}}{d_{\mathrm{x}}} \\
& \frac{\partial E d_{\mathrm{y}}^{\mathrm{t}}}{\partial t_{\mathrm{x}}}>0 \quad \text { iff } \quad \frac{2 \beta}{\gamma}<\frac{d_{\mathrm{y}}}{\eta_{\mathrm{x}} d_{\mathrm{x}}}
\end{aligned}
$$

As before, a foreign unilateral trade liberalization shifts the pollution-intensive production away from the dirty country towards the clean country. Again, as long as the foreign country does not bear a large fraction of the home pollution (i.e., as long as the pollution spillover parameter from home, $\eta_{\mathrm{x}}$, is sufficiently small), the dirty country can improve the quality of its environment by unilaterally liberalizing trade. 
The interesting point here is that the clean country doe not necessarily suffer from higher pollution in the post-liberalization equilibrium. Indeed, the quality of its environment can improve, even though it ends up producing a greater quantity of the polluting good. This is possible if its new level of clean production generates less pollution than that borne previously under the foreign pollution spillover. For this to be true, $d_{\mathrm{x}}$ must be relatively low and $\eta_{\mathrm{y}} d_{\mathrm{y}}$ relatively large.

Again, provided that the foreign relative pollution differential exceeds the product differential, we can summarize these results as follows:

Proposition 3 Assuming that pollution is transboundary, the dirty country can improve its environment by unilaterally liberalizing trade. The clean country's environment can also be improved if its environmental standards are high enough.

\subsubsection{Global Pollution}

When pollution is global, the environmental damage is determined by the aggregate production of pollution-intensive good (regardless of whether it is produced at home or abroad) and it is identical in both countries. This global environmental damage can be expressed as:

$$
E d^{\mathrm{g}}=d_{\mathrm{x}}\left(x_{1}+x_{2}\right)+d_{\mathrm{y}}\left(y_{1}+y_{2}\right)
$$

According to this expression, the effects of a unilateral trade liberalization on the global environmental damage of, respectively, the home and the foreign country, are given by:

$$
\begin{aligned}
& \frac{\partial E d^{\mathrm{g}}}{\partial t_{\mathrm{y}}}>0 \quad \text { iff } \quad \frac{2 \beta}{\gamma}<\frac{d_{\mathrm{x}}}{d_{\mathrm{y}}} \\
& \frac{\partial E d^{\mathrm{g}}}{\partial t_{\mathrm{x}}}>0 \quad \text { iff } \quad \frac{2 \beta}{\gamma}<\frac{d_{\mathrm{y}}}{d_{\mathrm{x}}}
\end{aligned}
$$


As before, we refer to the left-hand side of these conditional statements as the product differential effect. But in the presence of global pollution, we refer to the right-hand side as the "absolute pollution differential" (equation (17) refers to the home absolute pollution differential, while equation (18) refers to the foreign absolute pollution differential).

By unilaterally liberalizing trade, the clean country transfers the production of the pollution-intensive good away from the clean country towards the dirty country. Since the rise in dirty production exceeds the reduction in clean production, the unilateral trade liberalization by the clean country always raises the global environmental damage. This is expressed in equation (18), where the conditional statement never holds and hence, $\partial E d^{\mathrm{g}} / \partial t_{\mathrm{y}}<0$.

This result may be reversed if the dirty country reduces its trade barriers, in which case a unilateral trade liberalization shifts the pollution-intensive production away from the dirty country towards the clean country, possibly raising the quality of the environment. While the aggregate production is higher in the post-liberalization equilibrium (which tends to support higher global pollution), the rise in the clean production exceeds the reduction in the dirty production. Thus, with a sufficiently large pollution differential, the dirty country can improve the quality of the environment by unilaterally liberalizing trade.

Assuming that the foreign relative pollution differential exceeds the product differential, these results can be summarized as follows.

Proposition 4 Assuming that pollution is global, a unilateral trade liberalization by the clean country deteriorates unambiguously the global environment. But a unilateral trade liberalization by the dirty country can still improve the quality of the global environment, provided a large pollution differential. 


\subsection{Multilateral Trade Liberalization}

Assume now that the home and foreign countries implement a multilateral trade liberalization, such that $d t_{\mathrm{x}}=d t_{\mathrm{y}}=d \tau<0$. Under this scenario, it is easy to show that a trade liberalization affects negatively the quality of the environment, regardless of whether pollution is local, transboundary or global. Indeed, the rise in exports exceeds (in absolute value) the fall in domestic production.

$$
\begin{gathered}
\frac{\partial x_{1}^{\mathrm{MTL}}}{\partial \tau}=\frac{\gamma}{D}>0 \\
\frac{\partial x_{2}^{\mathrm{MTL}}}{\partial \tau}=-\frac{2 \beta}{D}<0 \\
\frac{\partial y_{1}^{\mathrm{MTL}}}{\partial \tau}=-\frac{2 \beta}{D}<0 \\
\frac{\partial y_{2}^{\mathrm{M} T L}}{\partial \tau}=\frac{\gamma}{D}>0
\end{gathered}
$$

Thus, a multilateral trade liberalization raises each country's overall pollution-intensive production, and hence, deteriorates each country's environmental quality. This is illustrated in the following expressions.

\subsubsection{Local Pollution}

When pollution is local, a multilateral trade liberalization, which raises each country's domestic pollution-intensive production, deteriorates inevitably the environmental quality in each country.

$$
\frac{\partial E d_{\mathbf{x}}^{l}}{\partial \tau}=\frac{d_{\mathbf{x}}}{D}(\gamma-2 \beta)<0
$$


The Impact of Intra-Industry Trade on the Environment

$$
\frac{\partial E d_{\mathrm{y}}^{1}}{\partial \tau}=\frac{d_{\mathrm{y}}}{D}(\gamma-2 \beta)<0
$$

\subsubsection{Transboundary Pollution}

When pollution is transboundary, a multilateral trade liberalization, which raises both the domestic and the foreign polluting production of pollution-intensive goods, deteriorates each country's environmental quality. This deterioration is positively related to the size of the pollution spillover parameter, $\eta_{\mathrm{y}}$.

$$
\begin{aligned}
& \frac{\partial E d_{\mathrm{x}}^{\mathrm{t}}}{\partial \tau}=\frac{1}{D}{ }^{\mathfrak{f}}\left(d_{\mathrm{x}}+\eta_{\mathrm{y}} d_{\mathrm{y}}\right)(\gamma-2 \beta)^{\mathfrak{a}}<0 \\
& \frac{\partial E d_{\mathrm{y}}^{\mathrm{t}}}{\partial \tau}=\frac{1}{D}\left[\left(\eta_{\mathrm{x}} d_{\mathrm{x}}+d_{\mathrm{y}}\right)(\gamma-2 \beta)\right]<0
\end{aligned}
$$

\subsubsection{Global Pollution}

Finally, when pollution is global, a multilateral trade liberalization, which raises the aggregate production of pollution-intensive goods, deteriorates unambiguously the quality of the global environment.

$$
\frac{\partial E d^{\mathrm{g}}}{\partial \tau}=\frac{1}{D}\left[\left(d_{\mathrm{x}}+d_{\mathrm{y}}\right)(\gamma-2 \beta)\right]<0
$$

These results can be summarized in the following terms:

Proposition 5 A multilateral trade liberalization always deteriorates the quality of the environment in both, the clean and the dirty country. This proposition holds regardless of whether pollution is local, transboundary or global, although its detrimental effects are smallest when pollution is local.

So far, we make the assumption that the polluting firms are quantity-setting oligopolists. However, we know from standard textbooks of industrial organization that this is not the 
only possible mode of competition. To test the robustness of our previous results, we have also considered the case where the polluting firms are price-setting producers, rather than quantity-setting producers. It is easy to show that under standard assumptions, the presence of a price-setting competition does not alter the results derived under a quantity-setting competition and all of the propositions derived in section 2.4 carry over to the case of Bertrand-Nash competition.

\section{Multiple Firms}

In this section, we extend the previous analysis and examine how our earlier results change when multiple firms produce the pollution-intensive good. In particular, we allow for $m$ $(n)$ firms to produce good $x(y)$, where $(m, n)>1$. Under this new specification, the profit function of, respectively, the home and the foreign firm needs to be modified as follows:

$$
\begin{gathered}
\pi_{\mathrm{x}}^{\mathrm{i}}=x_{1} p_{\mathrm{x}_{1}}\left(X_{1}, Y_{1}\right)+x_{2} p_{\mathrm{x}_{2}}\left(X_{2}, Y_{2}\right)-e_{\mathrm{x}}\left(x_{1}+x_{2}\right)-t_{\mathrm{x}} x_{2} \\
\pi_{\mathrm{y}}^{\mathrm{i}}=y_{1} p_{\mathrm{y} 1}\left(X_{1}, Y_{1}\right)+y_{2} p_{\mathrm{y} 2}\left(X_{2}, Y_{2}\right)-e_{\mathrm{y}}\left(y_{1}+y_{2}\right)-t_{\mathrm{y}} y_{1}
\end{gathered}
$$

where $X_{\mathrm{i}}=x_{\mathrm{i}}+(m-1) v_{\mathrm{i}}$ and $Y_{\mathrm{i}}=y_{\mathrm{i}}+(n-1) z_{\mathrm{i}}($ for $i=1,2)$. While both $x$ and $v$ are produced in the home country, good $x$ is produced by a single firm and good $v$ is produced by the remaining $(m-1)$ firms in the domestic industry. Similarly for the foreign country, where good $y$ is produced by a single foreign firm, while good $z$ is produced by the remaining $(n-1)$ foreign firms in the industry. If we assume now that all the firms in a given country 
produce a similar good, we can now drop the inter-firm product differential and focus on the national product differential, such that $x_{\mathrm{i}}=v_{\mathrm{i}}$ and $y_{\mathrm{i}}=z_{\mathrm{i}}$. As before, the subscripts indicate whether a polluting good is sold in the home market (1) or in the foreign market (2).

In the presence of multiple firms, the optimal outputs require:

$$
\begin{aligned}
& x_{1}^{\mathrm{CN}}=\frac{(n+1) \beta\left(\alpha_{1}-e_{\mathrm{x}}\right)-n \gamma\left(\alpha_{2}-e_{\mathrm{y}}-t_{\mathrm{y}}\right)}{E} \\
& x_{2}^{\mathrm{CN}}=\frac{(n+1) \beta\left(\alpha_{1}-e_{\mathrm{x}}-t_{\mathrm{x}}\right)-n \gamma\left(\alpha_{2}-e_{\mathrm{y}}\right)}{E} \\
& y_{1}^{\mathrm{CN}}=\frac{(m+1) \beta\left(\alpha_{2}-e_{\mathrm{y}}-t_{\mathrm{y}}\right)-m \gamma\left(\alpha_{1}-e_{\mathrm{x}}\right)}{E} \\
& y_{2}^{\mathrm{CN}}=\frac{(m+1) \beta\left(\alpha_{2}-e_{\mathrm{y}}\right)-m \gamma\left(\alpha_{1}-e_{\mathrm{x}}-t_{\mathrm{x}}\right)}{E}
\end{aligned}
$$

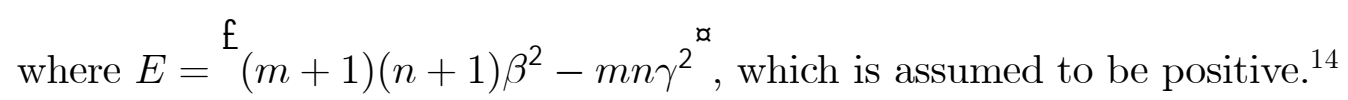

\subsection{Conditions for Intra-Industry Trade}

The existence of two-way trade requires that $x_{2}^{\mathrm{CN}}>0$ and $y_{1}^{\mathrm{CN}}>0$. Thus, the conditions for intra-industry trade can be expressed as:

$$
\begin{aligned}
& x_{2}>0 \text { iff } \stackrel{\mu}{n+1}_{n}^{\text {П }} \frac{\beta}{\gamma}>\frac{\left(\alpha_{2}-e_{\mathbf{y}}\right)}{\left(\alpha_{1}-e_{\mathbf{x}}-t_{\mathbf{x}}\right)} \\
& y_{1}>0 \text { iff } \frac{m+1}{m}^{\boldsymbol{\mu}} \frac{\beta}{\gamma}>\frac{\left(\alpha_{2}-e_{\mathbf{y}}-t_{\mathbf{y}}\right)}{\left(\alpha_{1}-e_{\mathbf{x}}\right)}
\end{aligned}
$$

According to the above conditions, intra-industry trade is more likely to occur in the presence of: (i) greater product differential (high $\beta_{\mathrm{i}} / \gamma$ ); (ii) low import tariffs, $t_{\mathrm{i}}$; and (iii) 14Note that $E>D$ for $(m, n)>1$. 
lower environmental standards imposed on the exporting country $i$ (high $\alpha_{\mathrm{i}}-e_{\mathrm{i}}$ ). Note that since $(q+1) / q<2$ (for $q=m, n)$, the conditions for intra-industry trade are more binding in the $m \times n$ case than under the basic case presented in section 2 .

\subsection{Unilateral Trade Liberalization}

The impacts of a trade liberalization on the demand for pollution-intensive goods are given by the following equations:

$$
\begin{gathered}
\frac{\partial x_{1}^{\mathrm{CN}}}{\partial t_{\mathrm{y}}}=\frac{n \gamma}{E}>0 \\
\frac{\partial y_{1}^{\mathrm{CN}}}{\partial t_{\mathrm{y}}}=-\frac{(m+1) \beta}{E}<0 \\
\frac{\partial x_{2}^{\mathrm{CN}}}{\partial t_{\mathrm{x}}}=-\frac{(n+1) \beta}{E}<0 \\
\frac{\partial y_{2}^{\mathrm{CN}}}{\partial t_{\mathrm{x}}}=\frac{m \gamma}{E}>0
\end{gathered}
$$

Clearly, the presence of multiple firms does not alter the proposition stated in section 2.3. It is interesting to point out, however, that it is not clear whether the effects of a unilateral liberalization on the environment will be larger or smaller (in absolute value) in the presence of multiple firms than in the presence of a single domestic firm. This will depend on the respective size of the determinants $(E$ and $D)$ and on the number of firms $(m$ and $n)$. 
The Impact of Intra-Industry Trade on the Environment

\subsection{Environmental Damage}

Assuming that in each country, multiple firms produce the pollution-intensive good, a unilateral trade liberalization has the same effects on the quality of the environment than those derived in section 2.4. Indeed, the presence of multiple firms does not alter the direction of the impact of a unilateral trade liberalization on the quality of the environment and all of the propositions stated in section 2.4 carry over to the context of multiple firms. These results can be summarized in the following expressions:

$$
\begin{aligned}
& \mu_{\frac{\partial E d_{\mathrm{i}}}{\partial t_{\mathrm{j}}}}^{\boldsymbol{\bigcap}_{\mathrm{m} \times \mathrm{n}}}=\frac{m n}{E}^{1 / 2} \gamma d_{\mathrm{i}}-\frac{\mu}{q}^{\mu} \beta \eta_{\mathrm{j}} d_{\mathrm{j}}{ }^{3 / 4} \\
& \mu_{\frac{\partial E d_{\mathrm{i}}}{\partial t_{\mathrm{i}}}}^{\boldsymbol{\emptyset}_{\mathrm{m} \times \mathrm{n}}}=\frac{m n}{E}{ }^{1 / 2} \gamma \eta_{\mathrm{i}} d_{\mathrm{i}}-\frac{q+1}{q}^{\mu} \beta d_{\mathrm{j}}{ }^{3 / 4}
\end{aligned}
$$

where $(i, j)=(x, y)$ for $i \neq j$ and $q=(m, n)$. The various scenarios under local, transboundary or global pollution can be represented by substituting $\eta_{\mathrm{i}}$ with the relevant pollution spillover parameter $\left(\eta_{\mathrm{i}}=0\right.$ for local pollution, $0<\eta_{\mathrm{i}}<1$ for transboundary pollution and $\eta_{\mathrm{i}}=1$ for global pollution). Again, these equations can be re-written in the following conditional statements:

$$
\begin{gathered}
\frac{\partial E d_{\mathrm{i}}}{\partial t_{\mathrm{j}}}>0 \text { iff } \frac{d_{\mathrm{i}}}{\eta_{\mathrm{j}} d_{\mathrm{j}}}>{ }^{\mu} \frac{q+1}{q} \frac{\text { ๆ }}{\gamma} \\
\frac{\partial E d_{\mathrm{i}}}{\partial t_{\mathrm{i}}}>0 \text { iff } \frac{\eta_{\mathrm{i}} d_{\mathrm{i}}}{d_{\mathrm{j}}}>{ }^{\mu} \frac{q+1}{q} \frac{\beta}{\gamma}
\end{gathered}
$$

While a unilateral trade liberalization affects the environment in the same direction under the $m \times n$ case than under the basic case presented in section 2.4, the magnitude of its 
effects may be greater or smaller, depending on the specific parameter values of the model. In particular, this will depend on the relative size of two conflicting effects. While the size of the determinants is larger in the $m \times n$ case than in the basic case $(E>D)$, the size of the own-price effects is smaller in the $m \times n$ case than in the basic case $\frac{q+1}{q}<2$. Nevertheless, two general remarks can be drawn from expressions (19) and (20):

(i) If a trade liberalization is good for the environment, it is not possible to determine whether the impact will be greater or smaller under the $m \times n$ case than under the basic case. Thus,

$$
-\infty<\frac{\partial E d_{\mathrm{s}}^{\mathrm{j}}}{\partial t_{\mathrm{s}}} \stackrel{\mathbf{I}_{\mathrm{m} \times \mathrm{n}}}{\lessgtr}{\stackrel{\mu}{\mu_{E d_{\mathrm{s}}^{\mathrm{j}}}}}^{\boldsymbol{ी}_{\mathrm{CN}}}<0 \quad(\text { for } s=x, y \text { and } j=l, t, g)
$$

(ii) If, however, a trade liberalization is bad for the environment, the impact on the environment will be smaller under the $m \times n$ case than under the basic case:

$$
0<\frac{\partial E d_{\mathrm{s}}^{\mathrm{j}}}{\partial t_{\mathrm{s}}}<\frac{\partial E d_{\mathrm{s}}^{\mathrm{j}}}{\partial t_{\mathrm{s}}} \quad \text { (for } s=x, y \text { and } j=l, t, g \text { ) }
$$

Proposition 6 The presence of multiple polluting firms does not alter the direction of the impact of a unilateral trade liberalization on the quality of the environment derived under the basic case in section 2.4. In terms of magnitude, however, the effects of trade liberalization are always smaller under the $m \times n$ case than under the basic case when trade liberalization is bad for the environment. If, however, trade liberalization is good for the environment, its effects may be greater or smaller under the $m \times n$ case than under the basic case, depending on the specific parameter values of the model.

\subsection{Multilateral Trade Liberalization}

In the presence of multiple firms, the effect of a multilateral trade liberalization on the environmental damage of country $i$ is given by:

$$
\frac{\partial E d_{\mathrm{i}}}{\partial \tau}=\frac{m n}{E}{ }^{1 / 4 \mu} \gamma-\frac{q+1}{q} \beta d_{\mathrm{i}}+\gamma-\frac{q+1}{q} \beta \eta_{\mathrm{j}} d_{\mathrm{j}}<0
$$


As before, by substituting the appropriate value for $\eta_{\mathrm{i}}$, the degree of pollution spillover, the above expressions illustrate the environmental damage under local, transboundary, and global pollution.

As in section 2.5, a multilateral trade liberalization always yields negative consequences for the quality of the environment. However, due to its higher determinant and lower crossprice effects, a multilateral trade liberalization is less damaging for the environment as the number of oligopolistic firms increases. This has an interesting implication for the role of competition policy in the context of environmental protection, namely, that in the presence of two-way trade anti-trust policies are pro-environment.

$$
0<\frac{\partial E d}{\partial \tau}^{\boldsymbol{q}_{\mathrm{m} \times \mathrm{n}}}<\frac{\partial E d}{\partial \tau}^{\boldsymbol{q}_{\mathrm{CN}}}
$$

Proposition 7 While a multilateral trade liberalization always deteriorates the quality of the environment, its detrimental effects decline as the number of oligopolistic firms increases.

\section{The Repeated Game}

\subsection{Collusion}

In the previous sections, we examine the potential compatibility between trade liberalization and improving the quality of the environment in a one-shot game. In reality, of course, firms do interact more than once. In standard repeated interactions, it is well-known that producers can cooperate for certain parameters of the discount rate. In the context of intra-industry trade, collusive intra-industry trade is only feasible if the goods are imperfect substitutes (Fung 1991). Thus, an additional condition is required concerning the substitutability of the polluting goods. In the present section, we continue to assume that the 
polluting firms produce a heterogeneous good and interact in an infinitely repeated game and that there exists a focal equilibrium around which they can cooperate. ${ }^{15}$

Assuming cooperation, it is easy to determine the equilibrium levels of output at which the firms produce, namely,

$$
\begin{aligned}
& x_{1}^{\mathrm{COL}}=\frac{\beta\left(\alpha_{1}-e_{\mathrm{x}}\right)-\gamma\left(\alpha_{2}-e_{\mathrm{y}}-t_{\mathrm{y}}\right)}{F} \\
& x_{2}^{\mathrm{COL}}=\frac{\beta\left(\alpha_{1}-e_{\mathrm{x}}-t_{\mathrm{x}}\right)-\gamma\left(\alpha_{2}-e_{\mathrm{y}}\right)}{F} \\
& y_{1}^{\mathrm{COL}}=\frac{\beta\left(\alpha_{2}-e_{\mathrm{y}}-t_{\mathrm{y}}\right)-\gamma\left(\alpha_{1}-e_{\mathrm{x}}\right)}{F} \\
& y_{2}^{\mathrm{COL}}=\frac{\beta\left(\alpha_{2}-e_{\mathrm{y}}\right)-\gamma\left(\alpha_{1}-e_{\mathrm{x}}-t_{\mathrm{x}}\right)}{F}
\end{aligned}
$$

where $F=2\left(\beta^{2}-\gamma^{2}\right)>0$. Since the determinant is higher under the basic Cournot-Nash case than under collusion $(D>F)$, it is not clear whether firms produce more or less under collusion than under a Cournot-Nash game. As will be shown below, this implies that the competition regime (i.e., Cournot-Nash competition versus trade collusion) may have ambiguous effects on the environment.

\subsection{Environmental Damage Under Collusion}

Assuming that a trade liberalization does not affect the sustainability of the trade cartel, the effects of a trade liberalization on the quality of the environment under trade collusion follow closely those derived in the basic Cournot-Nash case. In particular, trade collusion does not 15 Since the existence of explicit cartels is an illegal practice in many countries, we focus on implicit collusion, that is, collusion that is sustainable in a non-cooperative setting. 
alter the direction of the impact of a trade liberalization on the environment under CournotNash competition and all of the propositions stated in section 2.4 hold in the context of trade collusion. These effects can be summarized as:

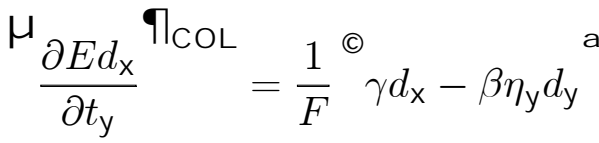

$$
\begin{aligned}
& { }^{\mu_{\partial E d_{\mathrm{y}}}}{ }^{\text {ी }_{\mathrm{COL}}}=\frac{1}{F}\left\{\gamma \eta_{\mathrm{x}} d_{\mathrm{x}}-\beta d_{\mathrm{y}}\right\} \\
& { }^{\mu^{\partial E d_{\mathrm{x}}}}{ }^{\text {ף }}{ }_{\mathrm{COL}}^{\mathrm{x}}=\frac{1}{F}\left\{\gamma d_{\mathrm{y}}-\beta \eta_{\mathrm{x}} d_{\mathrm{x}}\right\} \\
& \boldsymbol{\mu}_{\frac{\partial E d_{\mathrm{y}}}{\partial t_{\mathrm{x}}}}^{\text {ी }_{\mathrm{COL}}}=\frac{1}{F} \stackrel{\text { C }}{\gamma} \eta_{\mathrm{y}} d_{\mathrm{y}}-\beta d_{\mathrm{x}}{ }^{\mathrm{a}}
\end{aligned}
$$

Again, to represent the various scenarios under local, transboundary or global pollution, it is sufficient to substitute the relevant parameter for the pollution spillover parameter, $\eta_{\mathrm{i}}$.

While a trade liberalization affects the environment in the same direction under collusion than under Cournot-Nash, the magnitude of its effects may be greater or smaller under trade collusion than under Cournot-Nash competition. In particular, two general remarks can be drawn from expressions (25)-(28):

(i) If trade liberalization is quality-improving, the impact on the environment will be greater under trade collusion than under standard Cournot-Nash competition:

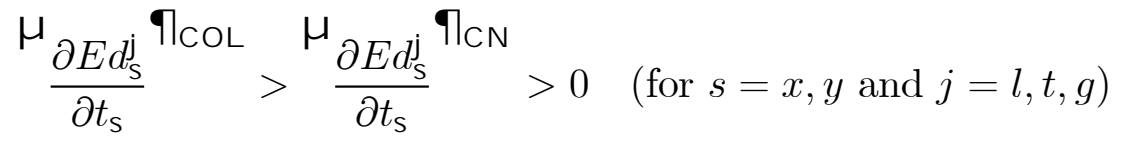

(ii) If, however, trade liberalization is environmentally-damaging, it is not possible to determine whether the impact will be greater or smaller under trade collusion than under the 
standard Cournot-Nash case. This will depend on the relative size of two conflicting effects.

On the one hand, the nominator in equations (25)-(28) is smaller under trade collusion than under the Cournot-Nash competition case derived in section 2.4, which reduces the (negative) effect of a trade liberalization on the quality of the environment. On the other hand, the determinant under Cournot-Nash competition is greater than that under trade collusion (i.e., $D>F$ ), which magnifies the (negative) effect on the environment. Clearly, the aggregate environmental effects will depend on the specific parameter values of the model.

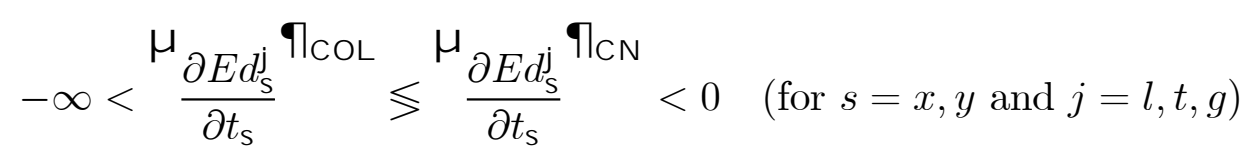

Proposition 8 Assuming that a unilateral trade liberalization does not affect the sustainability of the existing trade cartel, its effects on the quality of the environment follow the same direction than those derived in section 2.4 under the standard Cournot-Nash competition. Concerning the magnitude of these environmental consequences, the effects of a trade liberalization are greater under trade collusion than under Cournot-Nash competition when trade liberalization is good for the environment. If, however, trade liberalization is environmentally-damaging, its impact may be greater or smaller under trade collusion than under Cournot-Nash competition, depending on the specific parameters of the model.

\subsection{Environmental Damage Under a Regime Shift}

So far, we assume that the trade liberalization does not affect the sustainability of the existing trade cartel. In reality, however, a sufficiently large trade liberalization can threaten the viability of the cartel, forcing firms to revert from a cartel regime to a competition regime. The central question of this sub-section is to determine whether a trade liberalization, which can generate a shift away from trade collusion toward trade competition, is likely to improve or worsen the quality of the environment. To answer this question, we need to consider two separate issues, namely: (i) the effect of a trade liberalization on the sustainability of 
the trade collusion; and (ii) in the presence of a regime shift (say, from trade collusion to Cournot-Nash competition), the effect of this shift on the quality of the environment.

We now turn to the first issue concerning the sustainability of trade collusion.

\subsubsection{Sustainability of Collusion}

We know that cooperation is self-enforcing as long as the one-period gain from cheating dominates the punishment discounted infinitely into the future. Let's consider the following simple set of trigger strategies: the polluting firms produce at the collusion output levels (given in equations (21)-(24)) until some firm cheats. As soon as one firm deviates, all firms move back to the Cournot-Nash output levels (given in equations (3)-(6)). Although these trigger strategies yield sub-game perfect equilibria, they are arguably not the most satisfactory way to model repeated interactions. But for our purpose, they allow to highlight the possible impact of trade liberalization on the quality of the environment in a simple dynamic setting.

We know from standard literature on game theory that the condition for sustainability can be expressed as:

$$
\rho<\frac{\pi_{\mathrm{s}_{\mathrm{i}}}^{\mathrm{COL}}-\pi_{\mathrm{s}_{\mathrm{i}}}^{\mathrm{CN}}}{\pi_{\mathrm{s}_{\mathrm{i}}}^{\mathrm{CH}}-\pi_{\mathrm{s}_{\mathrm{i}}}^{\mathrm{CN}}} \equiv r_{\mathrm{s}_{\mathrm{i}}}^{\mathrm{C}} \quad(s=x, y \quad \text { and } \quad i=1,2)
$$

where $\rho$ is the discount rate, $r_{\mathrm{S}_{\mathrm{i}}}^{\mathrm{C}}$ the critical interest rate, and $\pi^{\mathrm{COL}}, \pi^{\mathrm{CN}}$ and $\pi^{\mathrm{CH}}$ the profits under, respectively, trade collusion, Cournot-Nash and cheating. According to this expression, trade collusion is feasible as long as the discount rate is smaller than the critical interest rate, and becomes less sustainable as the critical interest rate decreases. In other 
words, the firm with the smallest critical interest rate is the firm most likely to switch back to non-collusive trade and is often referred to as the 'weak link'.

Although there are four critical rates, $r_{\mathbf{x}_{\mathrm{i}}}^{\mathrm{c}}$ and $r_{\mathbf{y}_{\mathrm{i}}}^{\mathrm{c}}(i=1,2)$, it is easy to show that in the presence of tariffs, $r_{\mathrm{x}_{1}}^{\mathrm{c}}>r_{\mathrm{x}_{2}}^{\mathrm{c}}$ and $r_{\mathrm{y}_{2}}^{\mathrm{c}}>r_{\mathrm{y}_{1}}^{\mathrm{c}}$, such that there remains only two relevant critical rates $r_{\mathrm{x}_{2}}^{\mathrm{c}}$ and $r_{\mathrm{y}_{1}}^{\mathrm{c}}$. With symmetric demand functions, the following relationship can be established:

$$
r_{\mathrm{y}_{1}}^{\mathrm{c}} \gtreqless r_{\mathrm{x}_{2}}^{\mathrm{c}} \quad \text { iff } \quad\left[2\left(\alpha_{2}-e_{\mathrm{y}}\right)-t_{\mathrm{y}}\right] \gtreqless\left[2\left(\alpha_{1}-e_{\mathrm{x}}\right)-t_{\mathrm{x}}\right]
$$

Clearly, the firm with the greatest competitive disadvantage has the smallest critical interest rate. Assuming that both countries start with an identical level of trade protection $\left(t_{\mathrm{x}}=t_{\mathrm{y}}\right)$, the clean country (with stricter pollution control) represents the weak link of the trade cartel and hence, the most likely to defect in the case of a widening of its competitive disadvantage. Thus, according to equation (30), a unilateral trade liberalization by the clean country $\left(d t_{\mathrm{y}}<0\right)$ weakens the trade cartel, while a trade liberalization by the dirty country $\left(d t_{\mathrm{x}}<0\right)$ strengthens the trade cartel. Finally, in the case of a multilateral trade liberalization, both critical rates decrease by the amount of the tariff reduction, making collusion less sustainable, as either both or only the weakest country defect the collusive equilibrium and revert to trade competition.

\subsubsection{Environmental Damage Differential}

In order to analyze the effects of a change in the competition regime on the quality of the environment, we need to compare the environmental damage under a trade collusion regime 
with that under a Cournot-Nash competition regime:

$$
\Delta E d_{\mathrm{s}} \equiv\left(E d_{\mathrm{s}}^{\mathrm{COL}}-E d_{\mathrm{s}}^{\mathrm{CN}}\right) \lesseqgtr 0 \quad \text { for } s=x, y
$$

We refer to the expression in equation (31) as the environmental differential (between a trade collusion regime and a Cournot-Nash competition regime). If this term is positive, the environmental damage is higher under trade collusion and a trade policy that breaks the cartel is beneficial to the environment. If, however, equation (31) is negative, a trade competition regime supports a higher level of environmental damage and a trade policy that promotes trade collusion is an environmental-friendly policy.

The environmental damage differential of, respectively, the home and the foreign country is given by:

$$
\begin{aligned}
& \left(E d_{\mathrm{x}}^{\mathrm{COL}}-E d_{\mathrm{x}}^{\mathrm{CN}}\right)=d_{\mathrm{x}}\left[\Delta x_{1}+\Delta x_{2}\right]+\eta_{\mathrm{y}} d_{\mathrm{y}}\left[\Delta y_{1}+\Delta y_{2}\right] \\
& \left(E d_{\mathrm{y}}^{\mathrm{COL}}-E d_{\mathrm{y}}^{\mathrm{CN}}\right)=\eta_{\mathrm{x}} d_{\mathrm{x}}\left[\Delta x_{1}+\Delta x_{2}\right]+d_{\mathrm{y}}\left[\Delta y_{1}+\Delta y_{2}\right]
\end{aligned}
$$

where

$$
\begin{aligned}
& \Delta x_{1}>0 \quad \text { iff } \quad A<\frac{\alpha-e_{\mathrm{x}}}{\alpha-e_{\mathrm{y}}-t_{\mathrm{y}}} \\
& \Delta x_{2}>0 \quad \text { iff } \quad A<\frac{\alpha-e_{\mathrm{x}}-t_{\mathrm{x}}}{\alpha-e_{\mathrm{y}}} \\
& \Delta y_{1}>0 \quad \text { iff } \quad A<\frac{\alpha-e_{\mathrm{y}}-t_{\mathrm{y}}}{\alpha-e_{\mathrm{x}}} \\
& \Delta y_{2}>0 \quad \text { iff } \quad A<\frac{\alpha-e_{\mathrm{y}}}{\alpha-e_{\mathrm{x}}-t_{\mathrm{x}}}
\end{aligned}
$$




$$
\begin{gathered}
{\left[\Delta x_{1}+\Delta x_{2}\right]>0 \quad \text { iff } \quad A<B \equiv \frac{2\left(\alpha-e_{\mathrm{x}}\right)-t_{\mathrm{x}}}{2\left(\alpha-e_{\mathrm{y}}\right)-t_{\mathrm{y}}}} \\
{\left[\Delta y_{1}+\Delta y_{2}\right]>0 \quad \text { iff } \quad A<C \equiv \frac{2\left(\alpha-e_{\mathrm{y}}\right)-t_{\mathrm{y}}}{2\left(\alpha-e_{\mathrm{x}}\right)-t_{\mathrm{x}}}} \\
A=\left(2 \beta^{2}+\gamma^{2}\right) / 3 \beta \gamma \geqslant 1
\end{gathered}
$$

The first term on the right-hand side of equation (32) represents the pollution associated with the production differential in the home country associated with switching from trade collusion to Cournot-Nash competition. The second term represents the foreign pollution spillovers associated with the production differential abroad. Similarly for equation (33), where the first term represents the home pollution spillovers associated with the production differential abroad and the second term represents the pollution associated with the production differential in the foreign country.

For future reference, we refer loosely to $A$ as the "product differentiation" effect and to $C$ as the "environmental standards" effect ( $B$ is simply the inverse of $C$ ). For the sake of tractability, we impose three further restrictions, which we assume to hold unless specified otherwise. First, we assume that both countries start with an identical level of trade protection $\left(t_{\mathrm{x}}=t_{\mathrm{y}}\right)$. This assumption implies that $C$ is always greater than 1 , given our earlier assumption that the clean country has also higher environmental standards ${ }^{16}$. Second, we assume that the environmental standards effect exceeds the product differentiation effect $(A<C)$. Finally, we assume that the pollution differential between the two countries is large, that is, that $d_{\mathrm{x}}$ is relatively small and $d_{\mathrm{y}}$ is relatively large.

\footnotetext{
16Note also that an increase in the pollution tax seems to be twice as important as an increase in the import tariff.
} 
We now turn to the analysis of how a trade liberalization, by strengthening or weakening the trade collusion, affects the environmental damage under local, transboundary and global pollution.

Local Pollution When pollution is local, the environmental damage differential between a collusion and a competition regime for, respectively, the home and the foreign country, is given by:

$$
\begin{gathered}
\Delta E d_{\mathrm{x}}^{1}=\left(\Delta x_{1}+\Delta x_{2}\right) d_{\mathrm{x}}<0 \\
\Delta E d_{\mathrm{y}}^{l}=\left(\Delta y_{1}+\Delta y_{2}\right) d_{\mathrm{y}}>0 \quad \text { iff } \quad A<C
\end{gathered}
$$

According to these equations, a unilateral trade liberalization by the home country, which weakens the trade cartel, is likely to worsen the quality of the environment in the home and to improve it in the foreign country.

It is interesting to note that, as far as the home country is concerned, a sufficient condition for trade liberalization to be environmentally-damaging is $e_{\mathrm{x}}$ to exceed $\left(e_{\mathrm{y}}+t_{\mathrm{y}}\right)$. This can be seen from equation (35), which indicates that $\Delta x_{2}$ is always negative given our assumptions. Thus, when the home firm has a competitive disadvantage in its own market, a shift from trade collusion to trade competition is bad for its environment.

While the result on the home environment is unambiguous, the impact of a trade liberalization on the foreign environment depends heavily on the assumption that the environmental standards effect exceeds the product differentiation effect. Indeed, if we relax this assump- 
tion and allow $A>C$, a trade liberalization by the home country (which weakens the trade cartel) is likely to deteriorate the quality of the environment in both countries.

Similarly in the case of a foreign unilateral trade liberalization (which strengthens the trade cartel), where the environmental quality in the home country benefits from lower pollution, while the foreign country (again, provided that $A<C$ ) suffers from higher environmental degradation.

Transboundary Pollution When pollution is transboundary, the environmental damage differential between a collusion and a competition regime for, respectively, the home and the foreign country is given by:

$$
\begin{aligned}
& \Delta E d_{\mathrm{x}}^{\mathrm{t}}=\left(\Delta x_{1}+\Delta x_{2}\right) d_{\mathrm{x}}+\left(\Delta y_{1}+\Delta y_{2}\right) \eta_{\mathrm{y}} d_{\mathrm{y}} \\
& \Delta E d_{\mathrm{y}}^{\mathrm{t}}=\left(\Delta x_{1}+\Delta x_{2}\right) \eta_{\mathrm{x}} d_{\mathrm{x}}+\left(\Delta y_{1}+\Delta y_{2}\right) d_{\mathrm{y}}
\end{aligned}
$$

We have already seen above that, according to our initial assumptions, the first term of the right-hand side of equation (41) is always negative, while the second term is positive, provided that $A<C$. In this case, a home trade liberalization can be beneficial to both countries, provided that the relative pollution differential between the two countries is sufficiently large. If, however, we relax our assumption that the environmental standards effect is greater than the product differentiation effect and assume that $A>C$, a trade liberalization by the home country, which weakens the trade cartel, is likely to deteriorate the quality of the environment in both countries, and more so the higher the foreign pollution spillover effect. 
Alternatively, under the assumption $A<C$, a trade liberalization by the foreign country, which strengthens the trade cartel, can be beneficial to both the home and the foreign environment, provided that the relative pollution differential is sufficiently large (that is, a relatively small $d_{\mathrm{x}} / \eta_{\mathrm{y}} d_{\mathrm{y}}$ for the home country and a relatively large $d_{\mathrm{y}} / \eta_{\mathrm{x}} d_{\mathrm{x}}$ for the foreign country). If, however, $A>C$, a foreign trade liberalization always supports a lower-pollution regime in both, the home and the foreign country.

Global Pollution When pollution is global, the environmental damage differential between a collusion and a competition regime is given by:

$$
\Delta E d^{g}=\left(\Delta x_{1}+\Delta x_{2}\right) d_{x}+\left(\Delta y_{1}+\Delta y_{2}\right) d_{y}
$$

Again, while the first term of the right-hand side is always negative, the second term is positive if we assume that $A<C$. Provided that the absolute pollution differential $d_{\mathrm{y}} / d_{\mathrm{x}}$ is large, the environmental damage is higher under collusion than under competition and a trade liberalization by the home country, which weakens the trade cartel, is likely to improve the quality of the global environment. If, however, we relax our assumption that the environmental standards effect is greater than the product differentiation effect and assume that $A>C$, a home trade liberalization deteriorates unambiguously the environment.

Alternatively, a trade liberalization by the foreign country, which strengthens the trade cartel, is likely to deteriorate the quality of the global environments, provided that the absolute pollution differential is large and that $A<C$.

Note that while the focus of the present paper concerns the effects of a trade liberalization 
on the quality of the environment, this model also highlights the way in which stricter environmental policies may not always produce the desired effects on the environment. For example, if the clean country were to increase its pollution tax to a point where it would break the trade cartel and revert to trade competition, an environmental-friendly policy (i.e., higher pollution control) would actually deteriorate the environmental quality.

Finally, if we assume that the home country is the dirty country (in the sense that $d_{\mathrm{x}}>d_{\mathrm{y}}$ ), while keeping our assumption that the home country imposes higher pollution taxes $\left(e_{\mathbf{x}}>e_{\mathbf{y}}\right)$, a home trade liberalization always deteriorates the environment, while a foreign trade liberalization always improves the environment.

Assuming that the absolute pollution differential between the two countries is large and that $A<C$, we can summarize the results in the following terms:

Proposition 9 A unilateral trade liberalization by the clean country, which weakens the trade cartel, is likely to improve the quality of the environment in both countries, while a unilateral trade liberalization by the dirty country, which strengthens the trade cartel, is likely to deteriorate the quality of the environment in both countries.

\section{When the Foreign Firm Engages in Tariff-Jumping FDI}

\subsection{Framework}

When tariff barriers are high, rather than producing the pollution-intensive good at home and exporting it abroad, a firm may choose to serve the foreign market by engaging in foreign direct investment (FDI) and setting up production plants abroad, so as to 'jump' these high tariff barriers. 


\section{The Impact of Intra-Industry Trade on the Environment}

In this section, we consider the case where only the foreign firm engages in FDI activities, while the home firm produces the pollution-intensive good at home and exports part of its production to the foreign market. In the next section, we will extend the analysis to the case where both countries engage simultaneously in FDI.

Throughout this section, we assume that the foreign firm uses the same production technology, regardless of whether the goods are produced at home or abroad. The corresponding profit function of, respectively, the home and the foreign firms is given by:

$$
\begin{gathered}
\pi_{\mathrm{x}}^{\mathrm{FDI}}=x_{1} p_{\mathrm{x} 1}+x_{2} p_{\mathrm{x} 2}-e_{\mathrm{x}}\left(x_{1}+x_{2}\right)-t_{\mathrm{x}} x_{1} \\
\pi_{\mathrm{y}}^{\mathrm{FDI}}=y_{1} p_{\mathrm{y} 1}+y_{2} p_{\mathrm{y} 2}-e_{\mathrm{x}} y_{1}-e_{\mathrm{y}} y_{2}-F_{\mathrm{y}}
\end{gathered}
$$

The profits of the FDI host country (i.e., the home country) increase with total sales revenues (from both, the domestic and the export market) and decreases with both the home pollution tax $\left(e_{\mathrm{x}}\right)$ and the foreign tariff $\left(t_{\mathrm{x}}\right)$. The profit function of the FDI source country (i.e., the foreign country) differs in two aspects. First, the foreign firm pays the home pollution tax $\left(e_{\mathbf{x}}\right)$ on the polluting good it produces in the home country and the foreign pollution tax $\left(e_{\mathrm{y}}\right)$ on the polluting good it produces in the foreign country. Second, it incurs a lump-sum set-up cost $F_{\mathrm{y}}$ to engage in FDI activities. The first-order profit maximization conditions yield the following optimal supply functions:

$$
\begin{gathered}
x_{1}^{\mathrm{FDI}}=\frac{2 \beta\left(\alpha_{1}-e_{\mathbf{x}}\right)-\gamma\left(\alpha_{2}-e_{\mathbf{x}}\right)}{D} \\
x_{2}^{\mathrm{FDI}}=\frac{2 \beta\left(\alpha_{1}-e_{\mathbf{x}}-t_{\mathbf{x}}\right)-\gamma\left(\alpha_{2}-e_{\mathbf{y}}\right)}{D}=x_{2}^{\mathrm{CN}}
\end{gathered}
$$




$$
\begin{gathered}
y_{1}^{\mathrm{FDI}}=\frac{2 \beta\left(\alpha_{2}-e_{\mathbf{x}}\right)-\gamma\left(\alpha_{1}-e_{\mathbf{x}}\right)}{D} \\
y_{2}^{\mathrm{FDI}}=\frac{2 \beta\left(\alpha_{2}-e_{\mathbf{y}}\right)-\gamma\left(\alpha_{1}-e_{\mathbf{x}}-t_{\mathbf{x}}\right)}{D}=y_{2}^{\mathrm{CN}}
\end{gathered}
$$

where $D=4 \beta^{2}-\gamma$. While the presence of foreign FDI activities in the home country does not alter the sales in the foreign market, it affects those in the home market. In particular, whether the home market sales are higher or lower under a FDI regime than under the standard Cournot-Nash regime described in section 2.1 depends crucially on the relationship between $e_{\mathrm{x}}$ and $\left(e_{\mathrm{y}}+t_{\mathrm{y}}\right)$. In particular,

$$
\begin{aligned}
& x_{1}^{\mathrm{FDI}} \gtreqless x_{1}^{\mathrm{CN}} \quad \text { if } \quad e_{\mathrm{x}} \gtreqless\left(e_{\mathrm{y}}+t_{\mathrm{y}}\right) \\
& y_{1}^{\mathrm{FDI}} \gtreqless y_{1}^{\mathrm{CN}} \text { if } \quad e_{\mathrm{x}} \lesseqgtr\left(e_{\mathrm{y}}+t_{\mathrm{y}}\right)
\end{aligned}
$$

Finally, the optimal profit functions in the presence of FDI are given by:

$$
\begin{aligned}
& \pi_{\mathrm{x}}^{\mathrm{FDI}}=\beta^{\mathrm{f}}\left(x_{1}^{\mathrm{FDI}}\right)^{2}+\left(x_{2}^{\mathrm{CN}}\right)^{2^{\mathfrak{Q}}} \\
& \pi_{\mathrm{y}}^{\mathrm{FDI}}=\beta^{\mathfrak{f}}\left(y_{1}^{\mathrm{FDI}}\right)^{2}+\left(y_{2}^{\mathrm{CN}}\right)^{2^{\mathfrak{\alpha}}}-F_{\mathrm{y}}
\end{aligned}
$$

\subsection{Condition for FDI}

The foreign country chooses to engage in FDI activities in the home country, if its profits are higher under a FDI regime than under an intra-industry trade regime. The relative profitability between these two regimes is given by:

$$
\pi_{\mathrm{y}}^{\mathrm{FDI}}-\pi_{\mathrm{y}}^{\mathrm{CN}}=\beta^{\mathfrak{f}}\left(y_{1}^{\mathrm{FDI}}\right)^{2}-\left(y_{2}^{\mathrm{CN}}\right)^{2^{\mathfrak{\alpha}}}-F_{\mathrm{y}}
$$


If this expression is positive, it is profitable for the foreign firm to invest abroad and hence, to incur the initial set-up cost necessary to produce $y_{1}$ in the home country. If $\left(\pi_{\mathrm{y}}^{\mathrm{FDI}}-\pi_{\mathrm{y}}^{\mathrm{CN}}\right)=0$, the foreign firm is indifferent between producing $y_{1}$ in the foreign country (and paying import tariffs to the home country) and incurring the initial set-up cost to produce $y_{1}$ in the home country (and evading the home country's import tariffs). Finally, $\left(\pi_{\mathrm{y}}^{\mathrm{FDI}}-\pi_{\mathrm{y}}^{\mathrm{CN}}\right)<0$ corresponds to the situation in which it is in the foreign firm's best interest to produce $y_{1}$ at home and to export its production abroad, rather than to invest and produce abroad.

The conditional expression given in (50) together with the foreign profit function given in (52) indicate that foreign export sales and hence, foreign profits, are always smaller under a FDI regime than under an exports regime when $e_{\mathbf{x}} \geqslant\left(e_{\mathbf{y}}+t_{\mathrm{y}}\right)$. In this situation, it is never profitable for the foreign firm to engage in FDI activities. Indeed, the foreign firm engages in FDI only when $e_{\mathrm{x}}<\left(e_{\mathrm{y}}+t_{\mathrm{y}}\right)$, that is, when a smaller tax burden is levied on the foreign good produced in the home country than on the foreign good produced in the foreign country and subsequently exported to the home country. While $e_{\mathbf{x}}<\left(e_{\mathbf{y}}+t_{\mathbf{y}}\right)$ is a necessary condition for the foreign firm to consider FDI activities, it is not a sufficient one. This can be seen from equations (53), where the firm's relative profitability requires not only to produce a higher level of output under a FDI regime than under an exports regime but also to cover its initial set-up cost $F_{\mathrm{y}}$ associated with FDI. Thus, we need an additional condition to determine under which conditions it is profitable for the foreign firm to engage in FDI activities. 
For given pollution taxes, there exists a critical tariff rate at which the foreign firm is indifferent between undertaking FDI in the home country and exporting $y_{1}$ to the home country. This critical tariff rate, $t_{\mathrm{y}}^{\mathrm{c}}$, can be determined by differentiating the foreign profit differential given in equation (53) with respect to the home import tariff $t_{\mathrm{y}}$, and by solving for the following quadratic solution:

$$
t_{\mathrm{y}}^{2}-A t_{\mathrm{y}}-B=0
$$

where

$$
\begin{gathered}
A=2\left(\alpha_{2}-e_{\mathrm{y}}\right)-{ }^{\mu}{ }^{1 / 2}\left(\alpha_{1}-e_{\mathrm{x}}\right)^{3 / 4} \\
B={ }^{1 / 2} e_{\mathrm{x}}^{2}-2 \alpha_{2}\left(e_{\mathrm{x}}-e_{\mathrm{y}}\right)-e_{\mathrm{y}}^{2^{\alpha}}+\frac{\gamma}{\beta}\left(\alpha_{1}-e_{\mathrm{x}}\right)\left(e_{\mathrm{x}}-e_{\mathrm{y}}\right)^{3 / 4}
\end{gathered}
$$

The foreign firm engages in FDI if the tariff level exceeds this critical tariff rate. Thus, the sufficient set of conditions for the foreign country to undertake FDI requires $e_{x}$ to be smaller than $\left(e_{\mathrm{y}}+t_{\mathrm{y}}\right)$ and $t_{\mathrm{y}}$ to be greater or equal to $t_{\mathrm{y}}^{\mathrm{c}}$.

Proposition 10 The foreign country engages in FDI activities under the following two conditions, namely: (i) if $e_{\mathrm{x}}$ is smaller than $\left(e_{\mathrm{y}}+t_{\mathrm{y}}\right)$; and (ii) if $t_{\mathrm{y}}$ is greater or equal to $t_{\mathrm{y}}^{\mathrm{c}}$.

\subsection{Unilateral Trade Liberalization}

In the previous section, we have shown that when $e_{\mathrm{x}} \geq\left(e_{\mathrm{y}}+t_{\mathrm{y}}\right)$, it is never profitable for the foreign firm to engage in FDI activities, in which case the foreign firm exports $y_{1}$ to the home country. In the context of the present paper, this is not an interesting situation since a unilateral trade liberalization by the home country $\left(d t_{\mathrm{y}}<0\right)$ does not alter the foreign 
country's initial decision to export and thus, yields the same results as those already derived earlier in section 2.3 .

If, however, $e_{\mathbf{x}}<\left(e_{\mathbf{y}}+t_{\mathrm{y}}\right)$, the foreign country may choose to either undertake FDI activities or export, depending on whether $t_{\mathrm{y}} \gtrless t_{\mathrm{y}}^{\mathrm{c}}$. In particular, when $t_{\mathrm{y}}>t_{\mathrm{y}}^{\mathrm{c}}$, it is more profitable for the foreign firm to incur the costs associated with FDI and to produce $y_{1}$ abroad. But when $t_{\mathrm{y}}<t_{\mathrm{y}}^{\mathrm{c}}$, it becomes more profitable for the foreign firm to produce $y_{1}$ at home and to export its production to the home market. This highlights an interesting implication for trade policy in the context of intra-industry trade.

Assuming that the environmental damage generated under a FDI regime is significantly different from that generated under an exports regime, a unilateral trade liberalization by the home country can affect the quality of the environment if it induces the foreign country to switch away from a FDI regime toward an exports regime. Clearly, the extent to which one country benefits from trade liberalization depends on several factors, including which country is liberalizing, which country is experiencing inward FDI, which regime is more harmful to the environment and which type of pollution is occurring.

We turn now to the environmental damage generated under a FDI regime.

\subsection{Environmental Damage Differential}

Assuming that the foreign country engages in FDI, the environmental damage borne by, respectively, the home and the foreign country is given by:

$$
E d_{\mathrm{x}}^{\mathrm{FDI}}=\stackrel{\mathfrak{f}}{d_{\mathrm{x}}}\left(x_{1}^{\mathrm{FDI}}+x_{2}^{\mathrm{CN}}\right)+d_{\mathrm{y}} y_{1}^{\mathrm{FDI}}+\eta_{\mathrm{y}} d_{\mathrm{y}} y_{2}^{\mathrm{CN}}
$$




$$
E d_{\mathrm{y}}^{\mathrm{FDI}}=d_{\mathrm{y}} y_{2}^{\mathrm{CN}}+\eta_{\mathrm{x}}{ }^{\mathfrak{f}} d_{\mathrm{x}}\left(x_{1}^{\mathrm{FDI}}+x_{2}^{\mathrm{CN}}\right)+d_{\mathrm{y}} y_{1}^{\mathrm{FDI}}
$$

Again, by substituting the appropriate value for $\eta_{\mathrm{i}}$, the degree of pollution spillover, the above expressions illustrate the environmental damage under local $\left(\eta_{\mathrm{i}}=0\right)$, transboundary $\left(0<\eta_{\mathrm{i}}<1\right)$, and global $\left(\eta_{\mathrm{i}}=1\right)$ pollution.

According to equation(55), the home country suffers from two sources of pollution. While the first source is caused by the polluting production taking place in the home country (generated by both, the home and the foreign firm), the second source is generated by the foreign pollution spillovers. Similarly for the foreign country, which suffers from the pollution caused by the polluting production taking place in the foreign country and from the pollution spillovers associated with the production taking place in the home country (generated by both, the home and the foreign firm).

By comparing the environmental damage produced under a FDI regime (given in equations (55) and (56)) with that produced under an intra-industry trade regime (given in equations (11) and (12)), it is now possible to determine which regime supports a higher level of pollution and hence, to examine the environmental consequence of a given trade policy.

\subsubsection{Local Pollution}

Assuming that pollution is local, the environmental damage differential between a FDI regime and an exports regime of, respectively, the home and the foreign country is given by: 


$$
\begin{aligned}
& \left(E d_{\mathrm{x}}^{\mathrm{FDI}}-E d_{\mathrm{x}}^{\mathrm{CN}}\right)^{\prime}=\frac{1}{D} \stackrel{\stackrel{C}{ }}{d_{\mathrm{y}} D y_{1}^{\mathrm{CN}}}+\left[\gamma d_{\mathrm{x}}-2 \beta d_{\mathrm{y}}\right]\left[e_{\mathrm{x}}-\left(e_{\mathrm{y}}+t_{\mathrm{y}}\right)\right]^{\underline{\mathrm{a}}}>0
\end{aligned}
$$

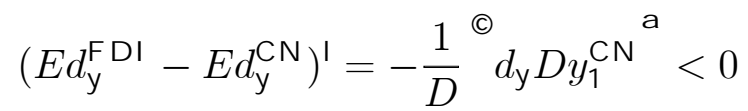

From our initial assumptions, we know that $e_{\mathrm{x}}<\left(e_{\mathrm{y}}+t_{\mathrm{y}}\right)$ and that $\gamma d_{\mathrm{x}}-2 \beta d_{\mathrm{y}}<0$. Thus, equation (57) is unambiguously positive and the home country (which hosts inward FDI) supports a higher level of pollution under a FDI regime than under an exports regime. From a trade policy perspective, the home country can improve its environment by liberalizing trade to a point where $t_{\mathrm{y}}<t_{\mathrm{y}}^{\mathrm{c}}$. Indeed, by reducing its tariff level below the foreign critical level, the home country discourages FDI and thereby, redirects the pollution-intensive production towards the foreign country. This policy improves the environmental quality in the home country and deteriorates it in the foreign country.

In summary, a trade liberalization by the home country, which induces the dirty country to switch from a FDI regime to an exports regime, unambiguously improves the environmental quality in the clean country, while deteriorating it in the dirty country.

\subsubsection{Transboundary Pollution}

When pollution is transboundary, the environmental damage differential between a FDI regime and an exports regime of, respectively, the home and the foreign country are given by:

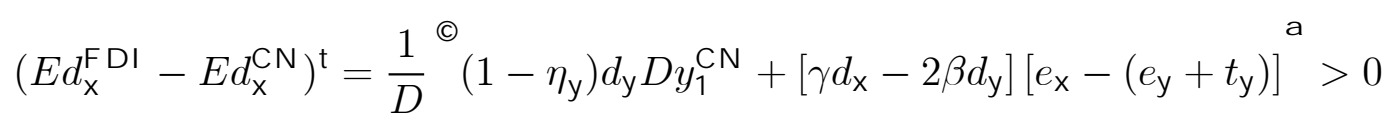




$$
\left(E d_{\mathrm{y}}^{\mathrm{FDI}}-E d_{\mathrm{y}}^{\mathrm{CN}}\right)^{\mathrm{t}}=\frac{1}{D} \stackrel{\stackrel{C}{ }}{\eta_{\mathrm{x}}}\left[\gamma d_{\mathrm{x}}-2 \beta d_{\mathrm{y}}\right]\left[e_{\mathrm{x}}-\left(e_{\mathrm{y}}+t_{\mathrm{y}}\right)\right]-\left(1-\eta_{\mathrm{x}}\right) d_{\mathrm{y}} D y_{1}^{\mathrm{CN}} \stackrel{\mathrm{a}}{\lessgtr} 0
$$

Since the environmental damage differential given in equation (59) is smaller under transboundary than under local pollution, the home country's environmental gain associated with a regime shift decreases as pollution starts to cross boundaries.

For the foreign country, however, the reverse may be true. While under local pollution, the environmental quality of the foreign country always deteriorates following a regime shift, when pollution is transboundary, its environmental quality can improve, provided that the home pollution spillover effects are large.

Thus, under transboundary pollution, a trade liberalization by the home country, which induces the dirty country to switch from a FDI regime to an exports regime, unambiguously improves the environmental quality in the clean country. The gains from such a regime shift decrease as the foreign pollution spillover increases. As far as the quality of the foreign environment is concerned, a regime shift can produce either positive or negative effects, depending on the size of the home pollution spillovers.

\subsubsection{Global Pollution}

When pollution is global, the environmental damage differential between a FDI regime and an exports regime of, respectively, the home and the foreign country is given by:

$$
\left(E d^{\mathrm{FDI}}-E d^{\mathrm{CN}}\right)^{\mathrm{g}}=\frac{1}{D}\left[\gamma d_{\mathrm{x}}-2 \beta d_{\mathrm{y}}\right]\left[e_{\mathrm{x}}-\left(e_{\mathrm{y}}+t_{\mathrm{y}}\right)\right]>0
$$

Again, according to our initial assumptions, we know that the sign of both square brack- 
ets is negative, making the environmental differential damage positive. Thus, under global pollution, a trade liberalization by the home country, which induces the dirty country to switch from a FDI regime to an exports regime, unambiguously improves the global environmental quality. The gains from such a regime shift are smallest when pollution is global and increase as the pollution spillover effects decrease.

Note that the above results are reversed if the home country is the dirty country (in the sense that $d_{\mathrm{x}}>d_{\mathrm{y}}$ ) and provided that the home absolute pollution differential exceeds the product differential. Under these assumptions, a home trade liberalization, which induces the clean country to switch from a FDI regime to an exports regime, unambiguously deteriorates the environmental quality in both, the clean and the dirty country.

These results can be summarized as follows:

Proposition 11 A unilateral trade liberalization by the clean country, which induces the dirty country to switch from a FDI regime to an exports regime, unambiguously improves the quality of the home environment. The gains from this regime shift are greatest when pollution is local and decrease as the foreign pollution spillovers increase. As far as the foreign country is concerned, while the environmental gains from such a regime shift are negative when pollution is local, they increase as the home pollution spillovers increase and become positive when pollution is global.

\section{When Both Countries Engage in FDI}

In the previous section, we consider the case where only the foreign firm engages in FDI and examine how a unilateral trade liberalization affects the environmental quality in both, the home and the foreign country under local, transboundary and global pollution. In this section, we extend our analysis to the case where both countries engage in FDI activities. Again, we assume that each firm applies its respective production technology and hence, 
generate the same level of pollution, regardless of its production location. The corresponding profit function of, respectively, the home country and the foreign country is given by:

$$
\begin{aligned}
& \pi_{\mathrm{x}}^{\mathrm{FDI}}=x_{1}\left(p_{\mathrm{x} 1}-e_{\mathrm{x}}\right)+x_{2}\left(p_{\mathrm{x}_{2}}-e_{\mathrm{y}}\right)-F_{\mathrm{x}} \\
& \pi_{\mathrm{y}}^{\mathrm{FDI}}=y_{1}\left(p_{\mathrm{y} 1}-e_{\mathrm{x}}\right)+y_{2}\left(p_{\mathrm{y} 2}-e_{\mathrm{y}}\right)-F_{\mathrm{y}}
\end{aligned}
$$

The profit function of a given firm $i(i=x, y)$ is given by its net sales revenues (net of pollution taxes) minus the lump-sump FDI set-up costs, $F_{\mathrm{i}}$. Note that in the presence of FDI, this firm pays the home pollution tax on the goods produced at home and the foreign pollution tax on the goods produced abroad.

The first-order profit maximization conditions yield the following optimal supply functions:

$$
\begin{aligned}
& x_{1}^{\mathrm{FDI}}=\frac{2 \beta\left(\alpha_{1}-e_{\mathbf{x}}\right)-\gamma\left(\alpha_{2}-e_{\mathbf{x}}\right)}{D} \\
& x_{2}^{\mathrm{FDI}}=\frac{2 \beta\left(\alpha_{1}-e_{\mathrm{y}}\right)-\gamma\left(\alpha_{2}-e_{\mathrm{y}}\right)}{D} \\
& y_{1}^{\mathrm{FDI}}=\frac{2 \beta\left(\alpha_{2}-e_{\mathrm{x}}\right)-\gamma\left(\alpha_{1}-e_{\mathrm{x}}\right)}{D} \\
& y_{2}^{\mathrm{FDI}}=\frac{2 \beta\left(\alpha_{2}-e_{\mathrm{y}}\right)-\gamma\left(\alpha_{1}-e_{\mathrm{y}}\right)}{D}
\end{aligned}
$$

where $D=4 \beta^{2}-\gamma^{2}$. Whether the sales are higher or lower under a FDI regime than under an exports regime depends crucially on the relationship between $e_{\mathrm{y}}$ and $\left(e_{\mathrm{x}}+t_{\mathrm{x}}\right)$ for the home country, and between $e_{\mathbf{x}}$ and $\left(e_{\mathbf{y}}+t_{\mathbf{y}}\right)$ for the foreign country.

$$
x_{1}^{\mathrm{FDI}} \gtreqless x_{1}^{\mathrm{CN}} \quad \text { iff } \quad e_{\mathrm{x}} \gtreqless\left(e_{\mathrm{y}}+t_{\mathrm{y}}\right)
$$




$$
\begin{aligned}
& x_{2}^{\mathrm{FDI}} \gtreqless x_{2}^{\mathrm{CN}} \quad \text { iff } \quad\left(e_{\mathrm{x}}+t_{\mathrm{x}}\right) \gtreqless e_{\mathrm{y}} \\
& y_{1}^{\mathrm{FDI}} \gtreqless y_{1}^{\mathrm{CN}} \quad \text { if } \quad e_{\mathrm{x}} \lesseqgtr\left(e_{\mathrm{y}}+t_{\mathrm{y}}\right) \\
& y_{2}^{\mathrm{FDI}} \gtreqless y_{2}^{\mathrm{CN}} \quad \text { if } \quad\left(e_{\mathrm{x}}+t_{\mathrm{x}}\right) \lesseqgtr e_{\mathrm{y}}
\end{aligned}
$$

In the presence of FDI activities, the optimal profit function of, respectively, the home and the foreign firm can be expressed as:

$$
\begin{aligned}
& \pi_{\mathrm{x}}^{\mathrm{FDI}}=\beta^{\mathrm{f}}\left(x_{1}^{\mathrm{FDI}}\right)^{2}+\left(x_{2}^{\mathrm{FDI}}\right)^{2^{\mathrm{W}}}-F_{\mathrm{x}} \\
& \pi_{\mathrm{y}}^{\mathrm{FDI}}=\beta^{\mathrm{f}}\left(y_{1}^{\mathrm{FDI}}\right)^{2}+\left(y_{2}^{\mathrm{FDI}}\right)^{2^{\mathrm{a}}}-F_{\mathrm{y}}
\end{aligned}
$$

\subsection{Conditions for FDI}

In order to analyze how a trade liberalization affects the quality of the environment in the presence of two-way FDI flows, we need to determine first under which conditions a firm chooses to undertake FDI. Among the conditional statements given in equations (67)-(70), it is possible to discard a certain number of possibilities and to focus on those that are relevant to the subject of the present paper.

For example, we know that when $e_{\mathrm{x}} \geqslant\left(e_{\mathrm{y}}+t_{\mathrm{y}}\right)$, the foreign sales in the home market $\left(y_{1}\right)$ are always lower under an FDI regime than under an exports regime and that it is never profitable for the foreign firm to engage in FDI activities in the home country (see equation (72)). From a trade policy perspective, a trade liberalization by the home country $\left(d t_{\mathrm{y}}<0\right)$ does not alter the foreign country's choice to export, and thus, yields the same results as 
those already derived in section 2.4. Similarly for the case when $e_{\mathbf{y}} \geqslant\left(e_{\mathbf{x}}+t_{\mathbf{x}}\right)$, in which case it is never profitable for the home country to engage in FDI activities.

The interesting cases for the purpose of this paper are restricted to the situations in which it is profitable for a firm to engage in FDI activities, namely, when $e_{\mathbf{y}}<e_{\mathbf{x}}+t_{\mathbf{x}}$ for the home firm and when $e_{\mathbf{x}}>\left(e_{\mathbf{y}}+t_{\mathbf{y}}\right)$ for the foreign firm. A necessary condition for a firm to engage in FDI activities requires the total tax burden levied abroad (i.e., the other country's pollution tax) to be smaller than the total tax burden levied at home (i.e., the domestic pollution tax plus the foreign tariff). This is, however, not a sufficient condition. Indeed, for FDI to be profitable, economic profits must also cover the initial set-up cost necessary to engage in FDI activities.

To determine the sufficient set of conditions for a firm to undertake FDI, we examine the firms' respective profitability conditions. In particular, it is only profitable for firm $i$ to invest abroad only if its profits are higher under a FDI regime than an exports regime, that is, $\left(\pi_{\mathrm{i}}^{\mathrm{FDI}}-\pi_{\mathrm{i}}^{\mathrm{CN}}\right)>0$. If, however, $\left(\pi_{\mathrm{i}}^{\mathrm{FDI}}-\pi_{\mathrm{i}}^{\mathrm{CN}}\right)=0$, firm $i$ is indifferent between producing at home (and paying import tariffs to the other country) and incurring the initial set-up cost to produce abroad (and evading the other country's import tariffs). Finally, $\left(\pi_{\mathrm{i}}^{\mathrm{FDI}}-\pi_{\mathrm{i}}^{\mathrm{CN}}\right)<0$ corresponds to the situation when it is in firm $i$ 's best interest to produce at home and to export abroad, rather than to engage in FDI activities abroad.

For example, for given pollution taxes $e_{\mathbf{y}}$ and $e_{\mathbf{x}}$, the relative profitability condition for 
the home country to engage in FDI in the foreign country is given by:

$$
\begin{gathered}
\pi_{\mathrm{x}}^{\mathrm{FDI}}-\pi_{\mathrm{x}}^{\mathrm{CN}}>0 \quad \text { iff } \\
\frac{\beta}{D^{2}} \stackrel{\complement}{\complement} \gamma^{2} t_{\mathrm{y}}^{2}+2 \gamma^{2}\left(e_{\mathrm{y}}-e_{\mathrm{x}}\right) t_{\mathrm{y}}+\left(e_{\mathrm{x}}-e_{\mathrm{y}}\right)^{2}\left(4 \beta^{2}+\gamma^{2}\right)+8 \beta^{2}\left(e_{\mathrm{x}}-e_{\mathrm{y}}\right) t_{\mathrm{x}}+4 \beta^{2} t_{\mathrm{x}}^{\underline{\underline{a}}}-F_{\mathrm{x}}>0
\end{gathered}
$$

By solving for this profitability condition, it is now possible to determine the critical tariff rate, $t_{\mathrm{x}}^{\mathrm{c}}$, at which point a firm is indifferent between engaging in FDI activities and exporting. Given this critical rate and assuming that $e_{\mathbf{y}}<\left(e_{\mathbf{x}}+t_{\mathbf{x}}\right)$, the home country engages in FDI provided that $t_{\mathrm{x}} \geqslant t_{\mathrm{x}}^{\mathrm{c}}$. Thus, the sufficient set of conditions for the home country to undertake FDI requires $e_{\mathrm{y}}$ to be smaller than $\left(e_{\mathrm{x}}+t_{\mathrm{x}}\right)$ and $t_{\mathrm{x}}$ to be greater or equal to $t_{\mathbf{x}}^{\mathrm{c}}$.

Proposition 12 A sufficient set of conditions for the home country to engage in FDI activities in the foreign country requires: (i) $e_{\mathrm{y}}$ to be strictly smaller than $\left(e_{\mathrm{x}}+t_{\mathrm{x}}\right)$; and (ii) $t_{\mathrm{x}}$ to be greater or equal to the critical tariff rate, $t_{\mathrm{x}}^{\mathrm{c}}$.

Similarly for the foreign country, where the relative profitability condition to engage in FDI activities in the home country is given by:

$$
\begin{gathered}
\pi_{\mathrm{y}}^{\mathrm{FDI}}-\pi_{\mathrm{y}}^{\mathrm{CN}}>0 \text { iff } \\
\frac{\beta}{D^{2}} \stackrel{\complement}{\complement} 4 \beta^{2} t_{\mathrm{y}}^{2}+8 \beta^{2}\left(e_{\mathrm{y}}-e_{\mathrm{x}}\right) t_{\mathrm{y}}+\left(e_{\mathrm{x}}-e_{\mathrm{y}}\right)^{2}\left(4 \beta^{2}+\gamma^{2}\right)+2 \gamma^{2}\left(e_{\mathrm{x}}-e_{\mathrm{y}}\right) t_{\mathrm{x}}+\gamma^{2} t_{\mathrm{x}}^{2^{\mathrm{a}}}-F_{\mathrm{y}}>0
\end{gathered}
$$

Again, expression (74) can be solved for $t_{\mathrm{y}}^{\mathrm{c}}$, the critical tariff rate at which point it becomes profitable for the foreign firm to switch from a FDI regime to an exports-oriented Cournot-Nash regime. Given this critical rate and assuming that $e_{\mathbf{x}}<\left(e_{\mathbf{y}}+t_{\mathbf{y}}\right)$, the foreign country engages in FDI if and only if $t_{\mathrm{y}} \geqslant t_{\mathrm{y}}^{\mathrm{c}}$.

Proposition 13 Similarly for the foreign country, a sufficient set of conditions for the foreign firm to engage in FDI activities in the home country requires: (i) $e_{\mathrm{x}}$ to be strictly smaller than $\left(e_{\mathrm{y}}+t_{\mathrm{y}}\right)$; and (ii) $t_{\mathrm{y}}$ to be greater or equal to the critical tariff rate, $t_{\mathrm{y}}^{\mathrm{c}}$. 


\subsection{Environmental Damage Differential}

If none of the firms are engaged in FDI activities, a multilateral trade liberalization does not influence their locational choice and hence, affects the environmental quality in the same way as in the basic case described in section 2.4. If, however, both firms are engaged in FDI activities, a multilateral trade liberalization can, under certain conditions, encourage the firms to switch away from FDI activities towards intra-industry trade. ${ }^{17}$ Provided that the environmental damage is significantly higher under a FDI regime than under an exports regime, such a trade liberalization improves the quality of the environment. But such a regime shift is beneficial to the environment only if the current FDI regime sustains a higher level of pollution than the exports regime, that is, if

$$
\left(E d_{\mathrm{i}}^{\mathrm{FDI}}-E d_{\mathrm{i}}^{\mathrm{CN}}\right)>0
$$

Assuming that both firms are engaging initially in FDI activities, we examine now how a trade liberalization, which induces both countries to switch from a FDI to an exports regime, affects the environmental damage under local, transboundary and global pollution.

\footnotetext{
17In particular, we have seen that the foreign firm engages in FDI under two conditions, namely, when $e_{\mathrm{x}}<\left(e_{\mathrm{y}}+t_{\mathrm{y}}\right)$ and when $t_{\mathrm{y}} \geqslant t_{\mathrm{y}}^{\mathrm{c}}$. In this case, a sufficient condition for the foreign country to adopt an exports regime requires $e_{\mathrm{x}} \geqslant\left(e_{\mathrm{y}}+t_{\mathrm{y}}\right)$. This can easily be achieved with a home trade liberalization. For the home country, however, an additional assumption is needed, namely, that the FDI set-up costs $F_{\mathrm{x}}$ are relatively large. This is necessary because in the absence of these set-up costs, a foreign trade liberalization is not sufficient to induce a regime shift upon the home country. Even in the event of foreign free-trade $\left(t_{\mathrm{x}}=0\right), e_{\mathrm{x}}$ would still be greater than $e_{\mathrm{y}}$ and it would still be preferable for the home firm to engage in FDI activities. In conclusion, provided that the FDI set-up costs are relatively large, a multilateral trade liberalization can induce the firms to switch from a FDI regime to an exports regime.
} 


\section{The Impact of Intra-Industry Trade on the Environment}

\subsubsection{Local Pollution}

Assuming that pollution is local, the environmental damage between a FDI regime and an exports regime of, respectively, the home and the foreign firm is given by:

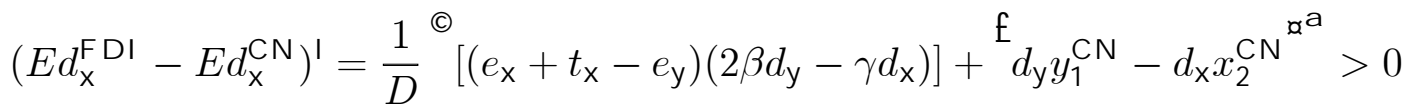

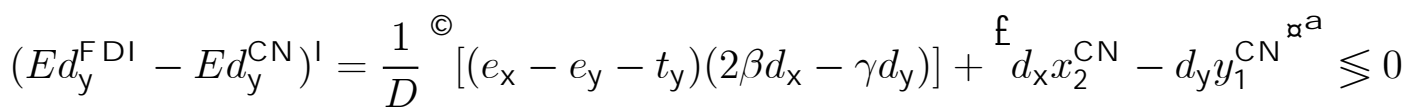

According to equations (75) and (76), the effects of a multilateral trade liberalization are ambiguous and depend on the parameter values of the model. Thus, in the absence of specific assumptions it is not clear which regime sustains a higher level of pollution, and hence, whether a trade liberalization is environmentally-friendly or environmentally-damaging. This is why we proceed with our analysis by introducing two new assumptions, namely, that the product differential exceeds the foreign pollution differential $\left(2 \beta d_{\mathbf{x}}-\gamma d_{\mathbf{y}}>0\right)$, which in turn, exceeds the foreign "sales differential" $\left(d_{\mathrm{y}} y_{1}^{\mathrm{CN}}-d_{\mathrm{x}} x_{2}^{\mathrm{CN}}>0\right)$.

A multilateral trade liberalization, which induces both firms to revert to an intra-industry trade regime, improves unambiguously the quality of the environment if the environmental damage differential is higher under a FDI regime than under an exports regime. We know from our earlier assumptions that the first square bracket in equation (75) is positive. According to our new assumptions, the second square bracket is also positive. Thus, the sign of equation (75) is positive and a multilateral trade liberalization, which induces a regime shift, improves the quality of the home environment. 
As far as the foreign country is concerned, according to our assumptions, the environmental damage differential given in equation (76) is negative and a multilateral trade liberalization, which induces a regime shift, deteriorates the quality of the foreign environment.

\subsubsection{Transboundary Pollution}

Assuming that pollution is transboundary and that both countries share the same pollution spillover parameter $\left(\eta_{\mathrm{x}}=\eta_{\mathrm{y}}=\eta\right)$, the environmental damage between a FDI regime and an exports regime for, respectively, the home and the foreign firm is given by:

$$
\begin{aligned}
\left(E d_{\mathrm{x}}^{\mathrm{FDI}}-E d_{\mathrm{x}}^{\mathrm{CN}}\right)^{\mathrm{t}} & =\frac{1}{D}\left\{\eta\left(e_{\mathrm{x}}+t_{\mathrm{x}}-e_{\mathrm{y}}\right)\left(2 \beta d_{\mathrm{x}}-\gamma d_{\mathrm{y}}\right)-\left[e_{\mathrm{x}}-\left(e_{\mathrm{y}}+t_{\mathrm{y}}\right)\right]\left(2 \beta d_{\mathrm{y}}-\gamma d_{\mathrm{x}}\right)\right\} \\
& +(1-\eta)^{\mathfrak{f}} d_{\mathrm{y}} y_{1}^{\mathrm{CN}}-d_{\mathrm{x}} x_{2}^{\mathrm{CN}} \mathbf{x} \\
\left(E d_{\mathrm{y}}^{\mathrm{FDI}}-E d_{\mathrm{y}}^{\mathrm{CN}}\right)^{\mathrm{t}} & =\frac{1}{D}\left\{\left(e_{\mathrm{x}}+t_{\mathrm{x}}-e_{\mathrm{y}}\right)\left(2 \beta d_{\mathrm{x}}-\gamma d_{\mathrm{y}}\right)-\eta\left[e_{\mathrm{x}}-\left(e_{\mathrm{y}}+t_{\mathrm{y}}\right)\right]\left(2 \beta d_{\mathrm{y}}-\gamma d_{\mathrm{x}}\right)\right\} \\
& +(1-\eta)^{\mathfrak{f}} d_{\mathrm{x}} x_{2}^{\mathrm{CN}}-d_{\mathrm{y}} y_{1}^{\mathrm{CN}} \mathfrak{x}
\end{aligned}
$$

Equations (77) and (78) indicates that if both countries engage in FDI and if the product differential $(2 \beta / \gamma)$ exceeds the foreign pollution differential $\left(d_{\mathbf{y}} / d_{\mathbf{x}}\right)$, a trade liberalization, which generates a shift away from FDI towards intra-industry trade, is good the home environment and has ambiguous effects on the foreign environment. In particular, such a multilateral trade liberalization deteriorates the quality of the foreign environment if the foreign pollution differential is much larger than the foreign sales differential. 


\subsubsection{Global Pollution}

Assuming that pollution is global, the environmental damage between a FDI regime and an exports regime for, respectively, the home and the foreign firm is given by:

$$
\left(E d^{\mathrm{FDI}}-E d^{\mathrm{CN}}\right)^{\mathrm{g}}=\frac{1}{D}\left\{\left(e_{\mathrm{x}}+t_{\mathrm{x}}-e_{\mathrm{y}}\right)\left(2 \beta d_{\mathrm{x}}-\gamma d_{\mathrm{y}}\right)-\left[e_{\mathrm{x}}-\left(e_{\mathrm{y}}+t_{\mathrm{y}}\right)\right]\left(2 \beta d_{\mathrm{y}}-\gamma d_{\mathrm{x}}\right)\right\}>0
$$

Equation (79) indicates that if both countries engage in FDI and if the product differential $(2 \beta / \gamma)$ exceeds the foreign pollution differential $\left(d_{\mathbf{y}} / d_{\mathbf{x}}\right)$, a trade liberalization, which generates a shift away from FDI towards intra-industry trade, improves unambiguously the global environment.

Assuming that the product differential exceeds the foreign pollution differential, which in turn, exceeds the foreign sales differential, the environmental effects of a multilateral trade liberalization in the presence of two-way FDI can be summarized as follows:

Proposition 14 A multilateral trade liberalization, which generates a shift away from FDI towards intra-industry trade, is always good for the quality of the home environment. But the effects of such a multilateral trade liberalization on the quality of the foreign environment are negative when pollution is local, ambiguous when pollution is transboundary and positive when pollution is global.

\section{Conclusion}

This paper offers a new causal mechanism linking international trade to changes in the environment. We argue that while trade expansion alters the composition of national output and hence, its environmental quality, its driving force may be international oligopolistic 
The Impact of Intra-Industry Trade on the Environment

rivalry rather than comparative advantage. While we do not claim to offer a complete resolution of the debate over trade and the environment, our contribution is to take a first step toward clarifying the role of intra-industry trade in determining how trade liberalization affects the quality of the environment.

First, our results show that when the driving forces that determine the environmental damage associated with trade expansion are fueled by neither comparative advantage nor cost differences but rather by oligopolistic competition, there is no justification for the traditional inter-industry factor-relocation hypotheses. The inconclusive empirical evidence found in support of the composition effect of trade supports our theoretical findings. ${ }^{18}$

Second, this paper sheds light on the question of whether there are still positive gains from trade when environmental degradation matters. In the context of intra-industry trade, a unilateral trade liberalization induces three effects, namely, a product variety effect, a procompetition effect and an environmental effect. While the first two effects are positive, we show that the third effect is not necessarily negative. For example, a trade liberalization by the dirty country always improves the quality of its own environment and can even be good for the environment of its trading partner, the clean country.

Third, although a multilateral trade liberalization raises the aggregate level of pollution in the basic Cournot-Nash case, our model indicates that the environmental damage under

18For a recent survey on the empirical literature, see Rauscher (1997). An excellent collection of papers is provided in Low (1992), where various aspects of this issue are discussed and reviewed. Finally, in the context of the present essay, it is interesting to highlight the fact that some studies have found positive effects of trade liberalization on the environment for certain highly polluting industries, such as the coal market (Burniaux et al., 1992). Others have tested and supported the statistical evidence that a significant share of international trade in the coal market takes the form of two-way trade (Bernhofen, 1999). Clearly, these observations call for a re-examination of the environmental consequences of oligopolistic intra-industry trade in highly polluting markets. 
intra-industry trade will not be as localized as predicted under standard inter-industry trade. This is an interesting finding, since the literature has long argued that different countries have different pollution assimilation capacities. Thus, as long as the environmental degradation borne by each country does not exceed its absorptive capacity, the positive variety and pro-competition effects may well outweigh the negative environmental effect. ${ }^{19}$

Fourth, we find that trade liberalization is better for the environment when the polluting firms compete in an oligopolistic framework than when they interact in a monopolistic setting. Again, this is an interesting observation in the context of competition policy. According to our model, anti-trust policies can be pro-environment. Finally, we find that under certain conditions our basic results can be reversed if the polluting firms are either colluding or engaging in FDI activities in the pre-liberalization equilibrium. For example, in the presence of two-way FDI a multilateral trade liberalization can actually improve the quality of the global environment.

It is important, however, to recognize the limitations of our analysis. Our analysis limits the channel linking trade and the environment to the composition effect via intra-industry trade and ignores other channels such as technological transfers and/or income effects. Also, our model suffers from extreme stylization. Nevertheless, the simple structure of our model is a virtue since it lays bare the basic relationship driving our results and enhances our understanding of the relationship between pollution and trade in the context of intra-industry

19Excellent discussions on countries' different pollution absorptive capacities can be found in Bhagwati and Srinivasan (1997) and Low and Safadi (1992). Note that while the authors highlight countries' variable capacities to assimilate pollution in defense against an international harmonization of environmental regulations, they both recognize that not all pollution is unacceptably bad for the environment. 
The Impact of Intra-Industry Trade on the Environment

trade. If anything, this paper highlights how much remains to be done in advancing our understanding of the many complex factors that influence the environmental consequences of an integrating and growing world economy. 


\section{References}

[1] Anderson, Kym and Richard Blackhurst, eds., 1992, The Greening of World Trade Issues, New York: Harvester Wheatsheaf.

[2] Antweiler, Werner, Brian R. Copeland and M. Scott Taylor, 1998, "Is Free Trade Good for the Environment?", NBER Working Paper Series, WP 6707.

[3] Beghin, John, David Roland-Holst and Dominique van der Mensbrugghe, 1995, American Journal of Agricultural Economics, 77(3):778-786, August.

[4] Beghin, John and Michel Potier (1997), "Effects of Trade Liberalization on the Environment in the Manufacturing Sector", The World Economy, 20(4):435-456, July.

[5] Beghin, John, David Roland-Holst and Dominique van der Mensbrugghe, 1994, "A Survey of the Trade and Environment Nexus: Global Dimensions", OECD Economic Studies, 23:167-192, Winter.

[6] Bernhofen, D.M., 1999, "Intra-Industry Trade and Strategic Interaction: Theory and Evidence", Journal of International Economics, 47(1):223-244, February.

[7] Bhagwati, Jagdish N. and T.N. Srinivasan, 1997, "Trade and the Environment: Does Environmental Diversity Detract form the Case for Free Trade?", in Bhagwati, Jagdish N. and Robert E. Hudec (eds.), Fair Trade \& Harmonization: Prerequisites for Free Trade?, Volume 1: Economic Analysis, Cambridge, Massachusetts: The MIT Press.

[8] Brander, James A., 1981, "Intra-Industry Trade in Identical Commodities", Journal of International Economics, 11(1):1-14, February.

[9] Brander, James and Paul Krugman, 1983, "A 'Reciprocal Dumping' Model of International Trade", Journal of International Economics, 15(3/4):313-321, November.

[10] Burniaux Jean-Marc, John P. Martin and Joaquim Oliveira-Martins, 1992, "The effects of Existing Trade Distortions in Energy Markets on the Costs of Policies to Reduce $\mathrm{CO}_{2}$ Emissions: Evidence from GREEN", OECD Economic Studies, 19:141-166, Winter.

[11] Cole M.A., A.J. Rayner and J.M. Bates (1998), "Trade Liberalization and the Environment: The Case of the Uruguay Round", The World Economy, 21(3):337-347, May.

[12] Copeland, Brian R. and M. Scott Taylor, 1999, "Trade, Spatial Separation and the Environment", Journal of International Economics, 47(1):137-168, February.

[13] Copeland, Brian R., 1996, "Pollution Content Tariffs, Environmental Rent Shifting, and the Control of Cross-Border Pollution", Journal of International Economics, 40(34):459-476, May.

[14] Copeland Brian R. and M. Scott Taylor, 1995, "Trade and the Environment: A Partial Synthesis", American Journal of Agricultural Economics, 77(3):765-772, August.

[15] Copeland Brian R. and M. Scott Taylor, 1995, "Trade and Transboundary Pollution", American Economic Review, 85(4):716-737, September. 
[16] Copeland Brian R. and M. Scott Taylor, 1994, "North-South Trade and the Environment", Quarterly Journal of Economics, 109(3):754-787, August.

[17] Durbin, Andrea C., 1995, "Trade and the Environment: The North-South Divide", Environment, 37(7):16-25, September.

[18] Fung K.C., 1991, "Collusive Intra-Industry Trade", Canadian Journal of Economics, 24(2):391-405, May.

[19] Fung, K.C., 1988, "Strategic Trade Policies, Differentiated Duopoly and Intra-Industry Trade", International Economic Journal, 2(3):19-34, Autumn.

[20] Greenaway, David and Johan Torstensson, 1997, "Back to the Future: Taking Stock on Intra-Industry Trade", Review of World Economics, 133(2):249-269, June.

[21] Greenaway, David and Chris Milner, 1987, "Intra-Industry Trade: Current Perspectives and Unresolved Issues", Review of World Economics, 123(1):39-57, March.

[22] Greenaway, David and Chris Milner, 1986, The Economics of Intra-Industry Trade, Oxford: Basil Blackwell Ltd.

[23] Greenaway, David and P.K.M. Tharakan (eds.), 1986, Imperfect Competition and International Trade: The Policy Aspects of Intra-Industry Trade, Sussex: Wheatsheaf Books Ltd.

[24] Grossman and Krueger, 1995, "Economic Growth and the Environment", Quarterly Journal of Economics, 110(2):353-377, May.

[25] Grossman and Krueger, 1993, "Environmental Impacts of a North American Free Trade Agreement", in P. Garber (ed.), The U.S.-Mexico Free Trade Agreement, Cambridge, MA: MIT Press.

[26] Hauer, Grant and Ford C. Runge, 1999, "Trade-Environment Linkages in the Resolution of Transboundary Externalities", The World Economy, 22(1):25-39, January.

[27] Helpman, Elhanan, 1987, "Imperfect Competition and International Trade: Opening Remarks", European Economic Review, 31(112):77-81, February/March.

[28] Helpman, Elhanan and Paul Krugman, 1985, Market Structure and Foreign Trade, Cambridge, MA: MIT Press.

[29] Hoekman, Bernard and Simeon Djankov, 1996, "Intra-Industry Trade, Foreign Direct Investment and the Reorientation of East European Exports", CEPR Discussion Paper, No.1377, April.

[30] Krugman, Paul, 1981, "Intra-Industry Specialization and the Gains from Trade", Journal of Political Economy, 89(5):959-973, October.

[31] Krugman, Paul R. and Maurice Obstfeld, 1997, International Economics: Theory and Policy, New York: Addison-Wesley, 4th edition.

[32] Lee, Hyun-Hoon and Young-Youn Lee, 1993, "Intra-Industry Trade in Manufactures: The Case of Korea", Review of World Economics, 129(1):159-171, March. 
[33] Levinson, Arik, 1997, "Environmental Regulations and Industry Location: International and Domestic Evidence", in Bhagwati, Jagdish N. and Robert E. Hudec (eds.), Fair Trade 8 Harmonization: Prerequisites for Free Trade?, Volume 1: Economic Analysis, Cambridge, Massachusetts: The MIT Press.

[34] Low, Patrick (ed.), 1992, International Trade and the Environment, World Bank Discussion Papers No. 159, Washington D.C., The World Bank.

[35] Menon, Jayant, 1994, "Trade Liberalization and Intra-Industry Specialization: the Australian Experience", Centre of Policy Studies Monash University, General paper No. G-107, June

[36] Menon, Jayant and Peter B. Dixon, 1997, "Measures of Intra-Industry Trade as Indicators of Factor Market Disruption", The Economic Record, 73(222):233-247, September.

[37] Menon, Jayant and Peter B. Dixon, 1996, "How Important is Intra-Industry Trade in Trade Growth?", Open Economics Review, 7(2):161-175, April.

[38] Rauscher, Michael, 1997, International Trade, Factor Movements, and the Environment, Oxford: Clarendon Press.

[39] Tharakan, P.K.M., 1984, "Intra-Industry Trade Between the Industrial Countries and the Developing World", European Economic Review, 26(2):213-226, November.

[40] Thompson, Peter and Strohm Laura A., 1996, "Trade and Environment Quality: A Review of the Evidence", Journal of Environment \& Development, 5(4):363-388, December.

[41] Tussie, Diana, 1999, "The Environment and International Trade Negotiations: Open Loops in the Developing World", The World Economy, 22(4):535-545, June.

[42] Venables, Anthony, J., 1985, "Trade and Trade Policy with Imperfect Competition: The Case of Identical Products and Free Entry", Journal of International Economics, 19(1/2):1-19, August. 